\title{
Natural disturbance and human land use as determinants of tropical forest dynamics: results from a forest simulator
}

\author{
María Uriarte,${ }^{1,6}$ Charles D. Canham,${ }^{2} \mathrm{~J}_{\text {ill }}$ Thompson, ${ }^{3} \mathrm{~J}$ ess K. Zimmerman, ${ }^{3}$ Lora Murphy,${ }^{1,2}$ \\ Alberto M. Sabat, ${ }^{4}$ Ned Fetcher,${ }^{5}$ and Bruce L. Haines ${ }^{7}$ \\ ${ }^{1}$ Department of Ecology, Evolution, and Environmental Biology, Columbia University, 1200 Amsterdam Avenue, \\ New York, New York 10027 USA \\ ${ }^{2}$ Cary Institute of Ecosystem Studies, Box AB, Millbrook, New York 12545 USA \\ ${ }^{3}$ Institute for Tropical Ecosystem Studies, Universidad de Puerto Rico, P.O. Box 23341, San Juan, Puerto Rico 00931-3341 USA \\ ${ }^{4}$ Department of Biology, Universidad de Puerto Rico, San Juan, Puerto Rico 00931 USA \\ ${ }^{5}$ Institute for Environmental Science and Sustainability, Wilkes University, Wilkes-Barre, Pennsylvania 18411 USA
}

\begin{abstract}
Forests are often subject to multiple, compounded disturbances, representing both natural and human-induced processes. Predicting forest dynamics requires that we consider how these disturbances interact to affect species demography. Here we present results of an individual-based, spatially explicit forest simulator that we developed to analyze the compounded effects of hurricane disturbance and land use legacies on the dynamics of a subtropical forest. We used data from the 16-ha Luquillo Forest Dynamics Plot in Puerto Rico, together with a reconstruction of historical wind damage, to parameterize the simulator. We used the model to ask two questions. (1) What are the implications of variation in hurricane frequency and severity for the long-term dynamics of forest composition, diversity, and structure? Both storm severity and frequency had striking effects on forest dynamics, composition, and structure. The periodicity of disturbance also played an important role, with periods of high hurricane activity fostering the establishment of species that may become rare in the absence of severe storms and quiescent periods allowing these species to reach reproductive size. Species responses to hurricane disturbance could not be predicted from their life history attributes. However, species perceived to be primary forest species exhibited low temporal variation in abundance through the simulations. (2) How do hurricanes and legacies from human land use interact to determine community structure and composition? Our results suggest that, over time, regardless of the storm regime, land use legacies will become less apparent but will lead to a forest community that contains a mixture of secondary and primary forest species formerly dominant in areas of different land use. In the long term, hurricane disturbance generated two communities with slightly greater similarity than those not subject to storms. Thus, the inclusion of hurricane disturbance does not alter the prediction that land use legacies in this tropical forest will diminish over time. Our simulations also highlight the contingent effects of human legacies on subsequent community dynamics, including the response to hurricane disturbance, therefore supporting the notion that compounded disturbances can interact in ways that cannot be predicted by the study of single disturbances. The widespread importance of land use as a large-scale disturbance makes it imperative that it be addressed as a fundamental ecological process.
\end{abstract}

Key words: disturbance theory; hurricanes; land use legacies; Luquillo Forest Dynamics Plot; SORTIE; subtropical wet forest.

\section{INTRODUCTION}

Ecologists have largely abandoned the viewpoint that ecosystems exhibit clearly defined equilibria to which they return via succession after disturbance. This paradigm, implicit in the idea of the balance of nature, has been replaced by a more nuanced one that emphasizes frequent disturbance and open, dynamic systems that may exhibit multiple successional pathways and equilibria that

Manuscript received 19 April 2008; revised 11 December 2008; accepted 17 December 2008. Corresponding Editor: J. J. Battles.

${ }^{6}$ E-mail: mu2126@columbia.edu

${ }^{7}$ Deceased. depend on environmental and historical context (Pickett et al. 1992, Wu and Loucks 1995). This new paradigm requires explicit attention to the spatial and temporal scales at which ecological processes, including natural disturbance, operate. It has the advantage that human activities can be readily incorporated as an inherent component of the ecosystem (Holling 2001, Pickett et al. 2005). This perspective implies that the state of an ecosystem at any particular point in space or time will be difficult to ascertain (Margalef 1968, Freelich and Reich 1999), an issue ecologists must address if they are going to forecast the future of the biosphere (Clark et al. 2001). 
Cyclonic storms (hurricanes, typhoons, and cyclones) represent the dominant natural disturbance in temperate and tropical forests in coastal regions of North, Central, and South America, the Indian subcontinent, southeast Asia and Africa, Indo-Malaysia, and northern Australia (Gray 1975, Boose et al. 1994, Everham and Brokaw 1996, Mabry et al. 1998, Platt et al. 2000, McNab et al. 2004). Recent studies have shown that the occurrence of hurricanes in the Atlantic is cyclical, alternating between relatively quiescent and storm-ridden phases, and exhibiting an upswing in activity since the late 20th century (Goldenberg et al. 2001). This periodicity is relevant to forest communities such as those in eastern Puerto Rico that suffered several severe storms in the early part of the 20th century (Miner Solá 2000, Boose et al. 2004), but suffered only one major storm between 1932 and 1989. Since 1989 the island has been struck by two severe hurricanes and several minor storms. In tropical forest communities, where individual trees may survive for 100 or more years, the cyclic nature of storm frequency must be considered in any effort to understand hurricane impacts on forest community dynamics.

Disturbance theory has generally distinguished between catastrophic, large-scale disturbance and smallscale, within-community disturbance (e.g., Romme et al. 1998). While classic disturbance theory has focused on patch size and the dynamics of patches following catastrophic disturbance (e.g., Levin and Paine 1974, Pickett and White 1985), hurricanes vary dramatically in intensity, both spatially within individual storms and temporally between storm events (Boose et al. 1994). Some of this variation can be attributed to striking differences among tree species in their response to wind, including their susceptibility to damage from wind of a given intensity, the nature of the damage they sustain from a given windstorm intensity, and their ability to recover from wind disturbance, at both the individual plant level (through repair of damage) and the population level (through reproduction, seedling establishment, and juvenile response to enhanced resource availability; e.g., Glitzenstein and Harcombe 1988, Peterson and Pickett 1991, Walker 1991, You and Petty 1991, Boucher et al. 1994, Zimmerman et al. 1994, Cooper-Ellis et al. 1999, Canham et al. 2001, Ostertag et al. 2005). Life history trade-offs in these complex responses to wind disturbance may reduce differences in fitness among species, thereby promoting the maintenance of species diversity over short time scales (Vandermeer et al. 1996, Chesson 2000). Although models strongly support the importance of life history trade-offs on forest dynamics and in the maintenance of species diversity in temperate forest (Pacala et al. 1996), a similar analysis has not been conducted for tropical forests.

While wind is the dominant cause of natural disturbance in many tropical forests, human disturbance is arguably a more pressing environmental issue in tropical forests worldwide. The extent of humanmodified degraded and secondary forests in the tropics was recently estimated at $8.50 \times 10^{8}$ hectares (ITTO 2002). In both temperate (Foster et al. 1998) and tropical (Grau et al. 2003) landscapes human disturbance often produces forests with different species compositions at local scales $\left(10-10000 \mathrm{~m}^{2}\right)$. These "new" forest communities may be relatively stable if human activities leave long-lasting legacies. Legacies can be created if human activities extirpate species over such large areas that they cannot recolonize a site, or if environmental conditions created by human land use (e.g., soil nutrient depletion) prevent species establishment (Zimmerman et al. 1995, Grau et al. 2003, Lugo and Helmer 2004). Human disturbance effects on forests may not be transient (Gómez-Pompa and Kaus 1992, Clark 1996). In Puerto Rico, human land use legacies are still visible after 75 years (Garcia-Montiel 2002, Thompson et al. 2002; see Plate 1), and in the temperate zone human agricultural legacies are evident 2000 years after abandonment (Dupouey et al. 2002, Dambrine et al. 2007).

Legacies of human disturbance can also influence how forest communities respond to natural disturbance, which in turn may determine the persistence of these human footprints (Zimmerman et al. 1995, Weir 1996, Foster et al. 2003, Uriarte et al. 2004b). Human land use increases the regional abundance of secondary forest species that are often less resistant to storm disturbance than primary forest species (Zimmerman et al. 1994, Foster et al. 1998, Thompson et al. 2002, Grau et al. 2003). By opening up the canopy, storm disturbance may be important in maintaining secondary species in forests with a history of human disturbance, thereby providing a positive feedback between human and natural disturbance (Foster et al. 1999, Grove et al. 2000, Boucher et al. 2001, Pascarella et al. 2004). Alternatively, natural disturbance may hasten the reestablishment of primary forest species, leading to dissipation of land use legacies.

In this paper, we use data from the 16-ha Luquillo Forest Dynamics Plot (LFDP) in Puerto Rico to parameterize an individually based, spatially explicit forest simulator. Our model allows us to go beyond the qualitative predictions of current disturbance/diversity theory (e.g., the Intermediate Disturbance Hypothesis; see Shea et al. 2004, Hughes et al. 2007) to explore the quantitative relationships between natural (hurricane) and anthropogenic (land use) disturbance, and the response of species to disturbance regimes, and to predict potential changes in species composition in this tropical forest. Models are, in fact, one of the few tools we have to explore the implications of the legacies of both human land use and past hurricanes for long-term tropical forest dynamics over long time scales. Our model is a descendant of SORTIE (Pacala et al. 1996), using a new, open-source platform for spatially explicit simulation of the neighborhood dynamics of forest ecosystems (SORTIE-ND). It is also the first application of SORTIE to a tropical forest. 
Our research involved three distinct steps. First we carried out a set of descriptive studies that characterized the effects of disturbance, both human and natural in origin, on the physical and biological components of the ecosystem. The studies documented spatial variation in the severity of hurricane disturbance and considered its immediate and long-term effects (e.g., Boose et al. 1994, 2004, Ogle et al. 2006; Appendix A). The second step involved comparative studies that took advantage of the spatial variation in disturbance to understand how changes in the biotic and abiotic environment affected the demography of component tree species. This step used a model selection paradigm (Johnson and Omland 2004), and principles of likelihood and information theory, to test hypotheses about the mechanistic basis for the effects of disturbance on plant demography (Uriarte et al. 2004a, 2005).

The final step used the simulation model to integrate the results of the first two steps and to explore the consequences of variation in disturbance type, severity, and frequency for the long-term dynamics of tree populations in this Puerto Rican forest. The model allowed us to focus on both transient and long-term dynamics resulting from natural disturbance, and to include the effects of land use history on spatial and temporal variation in community dynamics. Specifically, we used the model to answer the following questions. (1) What are the implications of variation in hurricane frequency and severity for the long-term dynamics of forest composition, diversity, and structure? (2) How do hurricanes and legacies from human land use in this forest interact with species-specific demography to determine community structure and composition? (3) Does hurricane disturbance promote or prevent the convergence of forest communities between areas with distinctly different land use histories?

\section{Study System}

As in previous research with SORTIE and descendant models (Pacala et al. 1996, Coates et al. 2003), field research and model development were tightly linked. Methods for our field studies (e.g., Uriarte et al. 2004a, 2005) were specifically designed to provide parameter estimates for the model, and results of the field studies were used to determine the appropriate structure of the model. Moreover, as in previous applications of the simulator, the field methods have been adapted to unique features of the current study system as well as limitations on field methods imposed by the study system (e.g., inability to use annual growth rings to reconstruct radial growth). Thus, while the basic structure of the simulator is derived from SORTIE, both the field methods and the algorithms for almost all of the behaviors (submodels) are new. We begin by presenting the study system including its disturbance regime, and then describe the structure of the simulator we have developed.

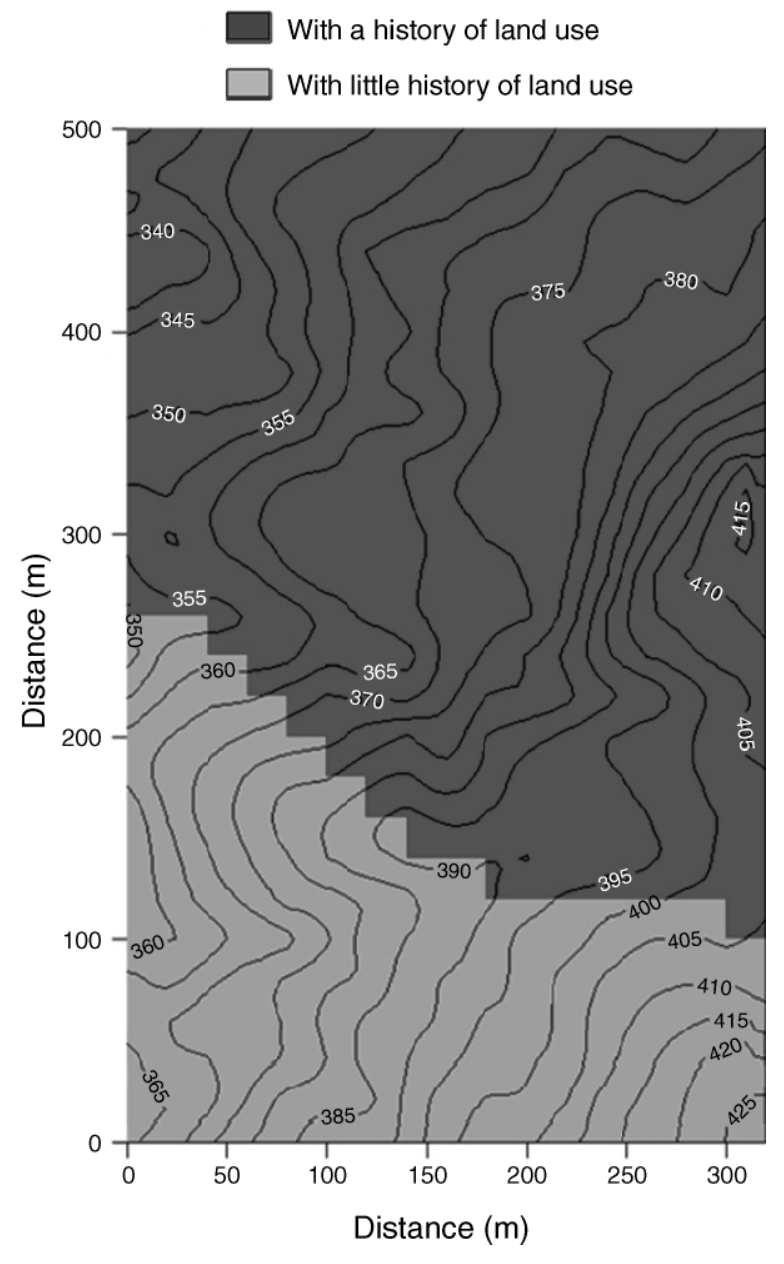

FIG. 1. Land use history of the 16-ha Luquillo Forest Dynamics Plot (LFDP), interpreted at the scale of $20 \times 20 \mathrm{~m}$ quadrats. See Thompson et al. (2002) for a full description of land use activities. The southern portion of the plot (with little history of land use) was only subject to some selective logging dating to the 1940s. The northern portion (with a history of land use) was clear cut in the 1920s and the site of some subsistence agriculture through the early 1930s.

\section{Study site and field surveys}

The Luquillo Forest Dynamics Plot (LFDP) is a 16ha permanent forest plot (southwest corner, $18^{\circ} 20^{\prime} \mathrm{N}$, $65^{\circ} 49^{\prime}$ W) located near El Verde Field Station in the Luquillo Mountains of northeastern Puerto Rico. The plot is $500 \mathrm{~m} \mathrm{~N}-\mathrm{S}$ and $320 \mathrm{~m} \mathrm{E}-\mathrm{W}$ and is divided into 400 $20 \times 20 \mathrm{~m}$ quadrats, with each quadrat subdivided into sixteen $5 \times 5 \mathrm{~m}$ subquadrats (Fig. 1). Vegetation and topography of this research area are typical of the tabonuco (Dacryodes excelsa) forest zone, except where human disturbance has altered the vegetation (Thompson et al. 2002). The forest is classified as subtropical wet in the Holdridge life zone system (Ewel and Whitmore 1973) and tropical montane in Walsh's (1996) tropical climate system. Rainfall averages $3500 \mathrm{~mm}$ per year. Elevation ranges from $333 \mathrm{~m}$ to $428 \mathrm{~m}$ above sea level. 
TABLE 1. Percentage of adult stems, maximum diameter at breast height (dbh), and successional status of 11 dominant species at the Luquillo Forest Dynamics Plot, Puerto Rico.

\begin{tabular}{|c|c|c|c|c|c|}
\hline Species & Family & $\begin{array}{c}\text { Adult } \\
\text { stems (\%) }\end{array}$ & $\mathrm{dbh} \dagger(\mathrm{cm})$ & $\begin{array}{c}\text { Successional } \\
\text { status: }\end{array}$ & Association \\
\hline Alchornea latifolia & Euphorbiaceae & 1.5 & 66.0 & secondary & 0 \\
\hline Casearia arborea & Salicaceae & 7.9 & 48.7 & secondary & + \\
\hline Cecropia schreberiana & Cecropiaceae & 4.0 & 32.2 & pioneer & + \\
\hline Dacryodes excelsa & Burseraceae & 7.4 & 82.2 & late & - \\
\hline Guarea guidonia & Meliaceae & 2.2 & 96.3 & late & 0 \\
\hline Inga laurina & Fabaceae & 4.0 & 78.8 & secondary & 0 \\
\hline Manilkara bidentata & Sapotaceae & 4.9 & 78.0 & late & - \\
\hline Prestoea acuminata & Arecaceae & 34.8 & & secondary & 0 \\
\hline Schefflera morototoni & Araliaceae & 1.5 & 75.0 & pioneer & + \\
\hline Sloanea berteriana & Elaeocarpaceae & 3.7 & 93.2 & late & - \\
\hline Tabebuia heterophylla & Bignoniaceae & 2.4 & 69.2 & secondary & 0 \\
\hline
\end{tabular}

Notes: Successional status and size distribution are given with respect to human land use: a plus $(+)$ indicates species with positive association with human-disturbed area; a minus (-) indicates a negative association; and zero ( 0$)$ indicates no association. Determinations are taken from Thompson et al. (2002).

$\dagger$ Maximum dbh is presented. Diameter is not a suitable measurement for the analysis of palm growth.

All of the soils are formed from volcaniclastic rock (Soil Survey 1995). Information from the LFDP contributes to the efforts of the Center for Tropical Forest Science (CTFS, Smithsonian Institution, Washington, D.C., USA) network of large tropical forest plots, a research endeavor aimed at furthering our understanding of tropical forests (Losos and Leigh 2004).

The LFDP was established in 1990. Censuses are carried out every five years and follow CTFS protocols with a few minor modifications (Condit 1998, Thompson et al. 2002). All free- standing woody stems $\geq 1 \mathrm{~cm}$ diameter at $130 \mathrm{~cm}$ from the ground (dbh) in the study area are tagged, identified to species, and their dbh measured. All stems are mapped within the plot but, in censuses starting in 1990 and 1995, individual trees 1-10 $\mathrm{cm}$ dbh were assigned to a $5 \times 5 \mathrm{~m}$ subquadrat without determining specific coordinates. For censuses in 2000 and 2005 the coordinates of the specific location for every stem was recorded. Trees are identified by sight in the field or from voucher specimens. Nomenclature follows Liogier (1985).

Portions of the area containing the LFDP were used for agriculture and logging before 1934 when the USDA Forest Service purchased the land, effectively ending human use of the area (Fig. 1). This land use history has more effect on present-day forest composition than do marked differences in topography, soil, and hurricane damage (García-Montiel 2002, Thompson et al. 2002). For the purposes of this project, the LFDP was divided into two distinct areas based on land use history (Thompson et al. 2002). The northern two-thirds of the plot experienced logging and small-scale farming of various crops interplanted among forest remnants early in the 20th century. The southern one-third of the plot experienced only light selective logging in the 1940s and has had no significant, direct human disturbance since then. The southern area of the LFDP is dominated by species typical of tabonuco forest, Dacryodes excelsa, Manilkara bidentata, Prestoea acuminata var. montana, and Sloanea berteriana (Table 1; Thompson et al. 2002).
With the exception of Prestoea acuminata, these species currently have a lower density and abundance in the northern two-thirds of the plot as a result of logging prior to 1934, and the northern area is currently dominated by a secondary forest species Casearia arborea. This spatial variation in land use history allows us to investigate the effects of land use legacies on plant community dynamics, including the capacity of species to recolonize areas disturbed by humans where their abundances were reduced.

Interestingly, land use history drives the spatial distribution of hurricane damage, since the species that colonize abandoned agricultural landscapes tend to be more vulnerable to hurricane damage than those from undisturbed habitats (Zimmerman et al. 1994, Everham 1996, Thompson et al. 2002). In particular, C. arborea is highly susceptible to windthrow (Zimmerman et al. 1994, Ogle et al. 2006; Appendix A), which causes an open forest canopy and soil disturbance that promotes the establishment of the pioneers Cecropia schreberiana and Schefflera morototoni (Table 1; Everham 1996). Thus, in contrast to studies of pristine, relatively undisturbed, and less dynamic forests, our research in the LFDP offers a perspective on natural disturbance, land use legacies, and tree community composition and diversity that few studies can provide and that is essential for both theory and forest management.

Species selection.-The LFDP contains 89 species of trees with stems $\geq 10 \mathrm{~cm}$ dbh distributed over 72 genera and 38 families (Thompson et al. 2002). Forty-five of the 89 tree species in the LFDP are rare (less than one stem $\geq 10 \mathrm{~cm} \mathrm{dbh} / \mathrm{ha}$ ) and over $75 \%$ of species have fewer than five stems/ha. Our research and modeling have focused on 11 canopy species that display a wide variation in life history characteristics as predicted by life history theory and for which we can obtain robust parameter estimates (Zimmerman et al. 1994, Loehle 2000, Uriarte et al. 2004a). Three of these 11 species, a palm Prestoea acuminata (Willdenow), HE Moore var. montana (Graham) Henderson and Galeano, Casearia 
arborea (IC Rich) Urban, and Dacryodes excelsa Vahl. make up nearly $50 \%$ of all adult (i.e., $\geq 10 \mathrm{~cm} \mathrm{dbh)} \mathrm{stems}$ in the LFDP (Table 1). These three species, together with the other eight species studied, Alchornea latifolia Sw., Cecropia schreberiana Miq., Guarea guidonia (L.) Sleumer, Inga laurina (Sw.) Willd, Manilkara bidentata (A.DC.) A. Chev., Schefflera morototoni (Aubl.) Maguire, Sloanea berteriana Choisy ex DC, and Tabebuia heterophylla (DC) Britton, represent $\sim 75 \%$ of the stems $\geq 10 \mathrm{~cm} \mathrm{dbh}$ in the plot (Table 1).

Tree censuses and hurricane damage.-The tabonuco forest in eastern Puerto Rico has a well-documented history of hurricane damage (Boose et al. 2004). Early in the last century, in 1928 and 1932, major hurricanes struck the LFDP area. After a 66-yr period with relatively little storm damage, Hurricane Hugo, a category 4 hurricane, struck the forest in September 1989 causing significant damage (see summary of effects in Tanner et al. [1991]). The first LFDP census started in 1990, the year after Hurricane Hugo. This census included an initial survey (September 1990 to February 1991) to prevent loss of data due to decomposition of trees killed or damaged by Hurricane Hugo (Zimmerman et al. 1994). The survey recorded several qualitative and quantitative observations on tree damage resulting from the hurricane, such as tip-up, and type of damage to stems, tree crowns, and branches. For the purposes of the model, damage observations were classified into three categories to represent the degree of hurricane injury for each stem $\geq 10 \mathrm{~cm}$ dbh: (1) no or light damage ( $\leq 25 \%$ of crown volume removed by the storm), (2) medium damage (25-75\% of crown volume lost through a combination of branch damage and crown break), or (3) heavy or complete damage $(>75 \%$ of the crown lost, stem snapped, root broken, or tip-up). Stems that were dead or severely damaged at the time of the survey were identified to species from bark and tree form. The initial tree damage survey was combined with two additional surveys comprised of all live stems $\geq 10 \mathrm{~cm} \mathrm{dbh}$ and all live stems $\geq 1 \mathrm{~cm}$ and $\leq 10 \mathrm{~cm}$ dbh censused from 1990 to 1993 according to CTFS methods. The second LFDP census was carried out between November 1994 and October 1996 and included all live stems $\geq 1 \mathrm{~cm} \mathrm{dbh}$ together with the status (dead or alive) of all stems tagged in the first census. The third and fourth censuses were conducted in the same manner as the second census and were started in 2000 and 2005, respectively. See Thompson et al. (2002) for more details of census methods.

As the forest was recovering from Hurricane Hugo, Hurricane Georges struck Puerto Rico in September 1998 with winds up to $150 \mathrm{~km} / \mathrm{hr}$ (category 3; Miner Solá 2000), but it was estimated to be a category 2 storm by the time it reached the forest. Although the effects of this second hurricane on the LFDP forest area were less acute than those of Hugo, Georges severely damaged $16 \%$ and defoliated $27 \%$ of adult trees in the LFDP (J. Thompson and J. K. Zimmerman, unpublished data).
Between November 1998 and April 1999 we selected 40 points in a regular $60 \times 60 \mathrm{~m}$ grid across the LFDP. In a $30 \times 30 \mathrm{~m}$ square around each of these center points, we assessed the degree of hurricane damage to all trees $(\geq 10 \mathrm{~cm} \mathrm{dbh})$ using similar methods to the ones described previously for Hurricane Hugo (i.e., classification into light, medium, or heavy damage).

\section{THe Model}

The model was implemented using the SORTIE-ND software, an open-source platform for spatially explicit simulation of neighborhood dynamics of forest ecosystems. The software consists of two main components: a graphical user interface (written in Java), and the core program (written in $\mathrm{C}++$ ), which contains libraries of all of the different behaviors (submodels) that can be invoked during execution of a run. The compiled software, the source code, programmer's guides, user guides, and documentation of all behaviors are available online. ${ }^{8}$ During the course of our research, we developed a number of new behaviors. These were added to the libraries and are thus available to other researchers at the web site (Appendix A).

\section{Model structure and parameterization}

Our model consists of a sequence of "behaviors," which simulate the population dynamics of the 11 canopy species given the contrasting human land use patterns within the LFDP and resulting from a variety of hurricane disturbance scenarios (Appendix A). For each behavior, our approach was to characterize functional relationships that reflect species life history traits. We expected that life history variation would generate tradeoffs between traits such as susceptibility to wind disturbance (e.g., Zimmerman et al. 1994), dispersal ability, and patterns of growth and survival (Uriarte et al. 2004a). Choice of the appropriate empirical functions and estimation of the parameters of the functions for each of the behaviors was tightly linked to our field research or analyses of existing LFDP data sets. Here we provide a brief overview of each of the model behaviors. More detailed descriptions of the field studies and empirical results are available in Uriarte et al. (2004a, 2005), Ogle et al. (2006), Uriarte and Papaik (2007), Canham et al. (in press), and at the SORTIE-ND web site (see Appendix A for details).

Hurricane disturbance regimes.-Puerto Rico is affected by Atlantic hurricanes that most often approach from the south and east (Miner Solá 2000). Simulation parameters for hurricane severity and frequency were derived from a reconstruction of historical wind damage for 85 storms that have affected Puerto Rico since European settlement in 1508 (Boose et al. 2004). Given the difficulty in obtaining direct local measurements of wind speed at a given location, we used descriptions of tree damage in the Fujita scale to develop a synthetic

\footnotetext{
${ }^{8}\langle$ http://www.sortie-nd.org/ $\rangle$
} 
TABLE 2. Return intervals for windstorms in the Luquillo forest in Puerto Rico, and description of likely forest damage from Boose et al. (2004).

\begin{tabular}{ccclc}
\hline \hline $\begin{array}{l}\text { Fujita } \\
\text { index }\end{array}$ & $\begin{array}{c}\text { Mean return } \\
\text { interval }(\mathrm{yr})\end{array}$ & $\begin{array}{c}\text { Sustained wind } \\
\text { speed }(\mathrm{m} / \mathrm{s})\end{array}$ & \multicolumn{1}{c}{ Estimated damage } & $\begin{array}{c}\text { Mortality } \\
\text { (proportion) }\end{array}$ \\
\hline F0 & 4 & $18-25$ & leaves and fruits broken & 0 \\
F1 & 6 & $26-35$ & trees blown down & $0.05-0.20$ \\
F2 & 15 & $36-47$ & extensive blow downs & $0.20-0.50$ \\
F3 & 50 & $48-62$ & most trees down & $0.50-0.70$ \\
\hline
\end{tabular}

Note: The Fujita index represents the approximate proportion of trees likely to be killed in a storm of a given intensity.

index of storm severity ranging from 0 to 1 . The index represents the approximate proportion of trees likely to be killed in a storm of a given intensity (Table 2). We equated this with the storm severity index in Canham et al. (2001; $S$ in Eq. 5). Technically, storm severity corresponds to the expected mean probability of mortality in a mixed stand with a size distribution of trees representative of the population.

We explored two alternative scenarios of hurricane frequency. First, we simply used the historical storm frequencies in Table 2 to generate individual storm events during a simulation. Second, we incorporated the observed multidecadal pattern in windstorm severity in the North Atlantic (Goldenberg et al. 2001). Comparing these two storm regimes allowed us to explore the effect of varying patterns of storm frequency on community dynamics. To simulate the multidecadal cyclical behavior, we calculated the probability of occurrence of a hurricane of a given intensity, $\operatorname{Pr}(H)$, as a function of the average frequency $(B)$ determined from Boose et al. (2004), Table 2, and $Y$, a sine function that generates the periodicity observed in the historical record:

$$
\operatorname{Pr}(H)=B \times Y .
$$

$Y$ takes the form

$$
Y=\sin \frac{\pi x}{2}+1
$$

where $x=4 t / A . A$ is the duration of the multidecadal cycle in years, and $t$ is the number of years since the start of the cycle. We used $A=50 \mathrm{yr}$ based on recently published data (Goldenberg et al. 2001). To assess the effect of variation in storm severity on forest dynamics, we compared these two hurricane scenarios to a regime of no severe storms (i.e., no storms above F1 severity).

Variation in storm damage as a function of species, size, and storm severity.-Our empirical analyses of the effects of Hurricanes Hugo and Georges on tree damage within the LFDP take advantage of the wide range of storm severity embedded within the two storms (e.g., Boose et al. 1994) to develop functional relationships for the (ordinal) level of damage (light, medium, heavy) to a stem as a function of species, size (dbh), and storm severity (Canham et al., in press). One of the fundamental challenges in developing these relationships is that we do not have accurate and independent estimates of storm severity within the plot during either storm.
Canham et al. (2001) developed a hierarchical logistic regression model using likelihood estimation that circumvents this problem by simultaneously estimating both the local storm severity and the parameters of the functions that determine the degree of damage to a stem as a function of species and size. Their analyses were categorical, predicting whether or not a tree was killed by a storm. For the LFDP data, we used a parallelslopes ordinal logistic model to extend the approach to predict the probability that an individual will experience any one of the three ordinal damage levels (light, medium, or heavy; Agresti 2002). Additional intercept terms were added to the model, so that the logits for the cumulative probability of a given ordinal level are a set of parallel lines with different intercepts. Thus, if $p_{j}=$ $\operatorname{Pr}\left(y \leq Y_{j} \mid X\right)$, i.e., the probability that an observation $y$ will be less than or equal to ordinal level $Y_{j}$ (e.g., damage class $2=$ medium damage; $j=1 \ldots n-1$ levels), given a vector $(X)$ of explanatory variables, then the probability that an event will fall into a single class $j$ (rather than the cumulative probability) is

$$
p_{j-1 \rightarrow j}=\operatorname{Pr}\left(y \leq Y_{j} \mid X\right)-\operatorname{Pr}\left(y \leq Y_{j-1} \mid X\right) .
$$

The probability of complete tree crown loss (damage class 3 ) is then

$$
p_{3}=1-\operatorname{Pr}\left(y \leq Y_{2} \mid X\right) .
$$

The probability that an individual stem will experience any given level of damage is predicted as a logistic function of taxonomic identity, individual tree size (dbh), and local storm severity $S$ (as assessed using a relative, quantitative index; Canham et al. 2001; C. D. Canham, J. Thompson, J. K. Zimmerman, and M. Uriarte, unpublished manuscript). The basic model for the cumulative probability of damage level $j$ for stem $i$ of species $s\left(p_{i s j}\right)$ is then

$$
\operatorname{logit}\left(p_{i s j}\right)=a_{j}+c_{s} S_{k} \mathrm{dbh}_{i}^{b_{s}}
$$

where $\mathrm{dbh}_{i}$ is the dbh of the $i$ th individual of species $s, c_{s}$ and $b_{s}$ are species-specific parameters (for $s=1 \ldots m$ species), and $S_{k}$ are the storm intensities for the $k=$ $1 \ldots n$ subplots (see Appendix A for a full description of estimation methods for this behavior).

In our model, damage has one of two potential effects on a tree: it can kill it outright or affect its subsequent growth and probability of survival. To model the first 
case, we used data from the initial 1990 census and logistic regression analyses to estimate the probability of mortality for each species given a dbh and specified damage category (light, intermediate, or severe damage; Appendix A, storm damage killer behavior). Previous studies have demonstrated that trees can regrow lost branches and repair damaged crowns within relatively short time periods (i.e., three years; Walker 1991, Ostertag et al. 2005), so trees that were recorded as damaged but did not immediately die from storm damage were assumed to recover to a healthy status within a three-year period. However, in that three-year period damage may have affected both tree diameter growth and probability of mortality (Uriarte et al. 2004a; see Sapling and adult tree growth and survival section below).

Effects of hurricanes on understory light regimes.-The next step was to quantify the effects of canopy damage on abiotic process, specifically light availability. We characterized changes in light availability in the forest understory after Hurricane Georges using fisheye photographs taken at each of the 40 points at the center of the $30 \times 30 \mathrm{~m}$ quadrats employed to assess tree damage (see Study system: Tree censuses and hurricane damage). Fisheye photographs were taken using a Nikon Coolpix digital camera mounted on a leveled tripod positioned at a height of $1.25 \mathrm{~m}$ from the ground. The first photographs were taken in March 1999 about five months after Hurricane Georges. In order to examine the nature and timescale of canopy recovery after the hurricane, a second set of photographs was taken at the same locations in June 2002, 44 months after Hurricane Georges. Additional fisheye photos were taken in July of 1999 and 2002, during our studies on the effects of light availability on seedling establishment on 150 plots distributed across the LFDP (see Uriarte et al. [2005] for further details on the seedling plot sampling design). All digital fisheye photographs were analyzed using GLA software (Frazer et al. 1999) that computes a gap light index (GLI) using a modification of the methods outlined in Canham (1988).

We combined our assessment of tree damage recorded after Hurricane Georges (1998) with the fisheye photographs to parameterize a linear regression model that predicted light levels at any given point in the forest as a function of the number of stems that were uprooted, broken, or had lost their crowns within a 15-m radius of the 40 fisheye photograph locations (Fig. 2). This approach allowed us to link the spatial variation in storm intensity to changes in canopy light transmission characteristics and the spatial variation in understory light levels after a hurricane.

Seedling recruitment.-In most applications of SORTIE, the processes of seed production, dispersal, and germination are subsumed into the net process of seedling recruitment, which is determined primarily by the fecundity, size, and spatial distribution of adult trees. Previous field studies have used inverse modeling of
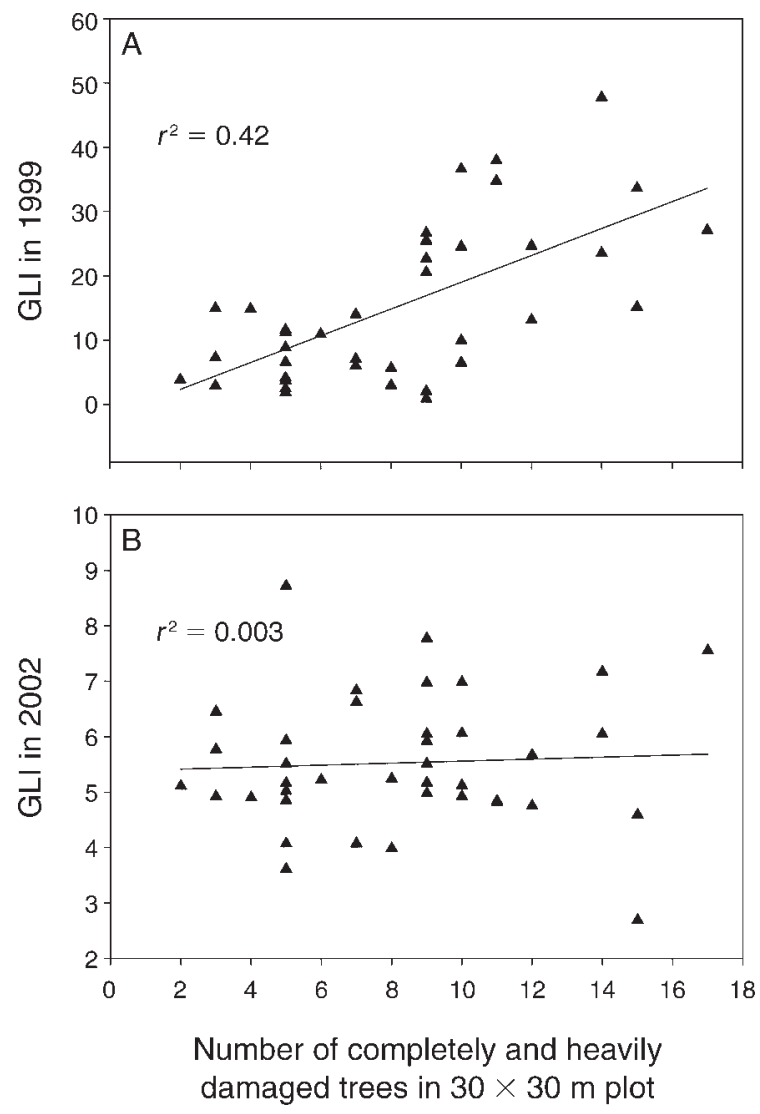

FIG. 2. Relationship between gap light index (GLI) and the number of stems that were heavily ( $>50-75 \%$ canopy loss) or completely ( $>75 \%$ canopy loss, stem snapped or uprooted) damaged (A) in 1999, a few months after Hurricane Georges, and (B) in 2002, 48 months after the hurricane.

spatial data on seedling establishment to derive parameters that specify seedling production as a function of parent tree size and dispersion of seedlings away from parent trees (Ribbens et al. 1994). The recruitment behavior in the present parameterization of SORTIE departs from this original approach by incorporating a number of additional processes uncovered by our analysis of seedling recruitment patterns following Hurricane Georges (Uriarte et al. 2005). These processes reflect the life history traits of our 11 target species and include (1) the minimum size at which trees of each species produce seeds, (2) the effects of light on seedling recruitment, and (3) density-dependent competition among conspecifics (see Uriarte et al. [2005] for a complete description of estimation methods).

Seedling demography censuses.-We used data from 150 seedling plots of $1 \times 2 \mathrm{~m}$ distributed in an array across the 16-ha plot to characterize the effects of hurricanes on seedling growth and survival. The seedling plots were established in 1999, soon after Hurricane Georges, and censused in 2000, 2002, and 2004. In each census, all seedlings of the 11 focal species $>10 \mathrm{~cm}$ in height and $<1 \mathrm{~cm}$ diameter were measured for height 
and root collar diameter, identified to species, and tagged with a unique number. In 1999 and 2002, we took fisheye photographs above each seedling plot to characterize the light environment. For some species, we did not have enough individuals for robust parameter estimation so in these cases we used data on seedling growth and survival after a hurricane collected for other projects in the Luquillo LTER (see Guzmán-Grajales and Walker 1991, Walker et al. 2003).

As expected from previous studies of the effect of hurricane damage on understory light levels (Fernandez and Fetcher 1991), our analyses of fisheye photographs showed that the pulse of light in the understory generated by canopy damage from Hurricane Georges had disappeared 24 months later (Fig. 2). We tested for the effects of density dependence on seedling growth and survival but their effects were negligible. Contrary to our expectations, we also found nonsignificant effects of light on seedling growth and survival. The effects of light on seedling demography may be too noisy to detect without consideration at the individual seedling level over multiple measurement periods (Clark et al. 2003). Moreover, measurement error associated with the use of digital fisheye cameras may have introduced additional biases in our estimation of light availability in seedling plots (Frazer et al. 2001). However, we did find differences in the effects of other covariates, such as size, on demographic rates between high and low light periods. Therefore, we excluded density dependence and light as covariates from subsequent analyses. Instead, we used data from the three seedling censuses to estimate growth and mortality parameters during a high light period (i.e., immediately after the hurricane between 1999 and 2002) and a low light period (i.e., after the canopy had recovered, represented by the 2002-2004 interval). For the simulation, high light parameters were used for the three years it took for trees to recover their canopy, while low light parameters were used at other times (see The model: Variation in storm damage).

Seedling growth.-We conducted separate analyses for the 2000-2002 and 2002-2004 censuses. We did not have enough seedlings to estimate seedling growth for $C$. schreberiana and D. excelsa, so we relied on an existing data set from the LEF for these analyses (GuzmánGrajales and Walker 1991, Walker et al. 2003). For the high light period, we assumed that growth was a function of seedling size at the start of the census interval and the number of years elapsed since the hurricane. The equation takes the following form:

$$
\operatorname{DiamGrowth}(\mathrm{cm})=a+b \times D \times \exp (-c \times T)
$$

where $D$ is root collar diameter in $\mathrm{cm}, T$ is the number of years elapsed since the hurricane, and $a, b$, and $c$ are estimated parameters. For the low light period, we excluded the time factor (i.e., $c=0$ ). Results of these regressions are presented in Appendix B. We used robust allometric relationships between root collar diameter and height (data not shown) to determine whether a seedling had grown large enough to be treated as a sapling.

Seedling survival.-We used a logit function and survival data for the high light and low light periods to calculate probability of survival $(p)$ as a function of root collar diameter (Appendix B):

$$
\operatorname{logit}(p)=a+b \times \operatorname{RootDiam}(\mathrm{cm}) .
$$

For some species, we did not find a significant relationship between diameter and survival; therefore the value of parameter $b$ was set to zero for these species. As with growth, we calculated separate parameters for high light and low light periods.

Sapling and adult tree growth and survival.-In contrast to previous approaches that related sapling growth to direct measures of understory light (e.g., Pacala et al. 1994), we estimated growth and mortality for each stem $\geq 1 \mathrm{~cm}$ dbh (i.e., saplings and adult trees) directly as a function of target tree sizes and the size of and distance to neighboring saplings and adult trees (Uriarte et al. 2004a). One benefit of this approach is that it effectively combines both aboveground and belowground competition into one net effect. In our analyses of LFDP data, we used a single function that applies to both saplings and adult trees, incorporating the effects that previous hurricane damage to both target and neighboring trees will have on growth and survival. See Uriarte et al. (2004a) for a detailed description of estimation methods and results. In brief, our growth model assumes that each target species has a maximum potential growth rate, which is adjusted to account for the size and taxonomic identity of the target tree, the structure and composition of its neighborhood, and previous hurricane damage to both the target tree and its neighbors. A similar approach was used to estimate survival.

The methods described in Uriarte et al. (2004a) rely on diameter growth for parameterization and as such are not suitable for the analyses of palm growth. Since the palm $P$. acuminata var. montana accounts for nearly a third of adult stems in the plot, we used a different approach to parameterize growth for this species. Rather than using diameter growth as a response variable and diameter as a predictor, we assumed that height growth was a function of palm height. The functional equation takes the following form:

HeightGrowth $=$ MaxGrowth

$$
\times \exp \left\{-0.5 \times\left[\ln \left(\frac{\text { Height }}{X_{o}}\right) / X_{b}\right]^{2}\right\}(8)
$$

where MaxGrowth, $X_{0}$, and $X_{b}$ are estimated parameters. Prior work at the LFDP has shown that $P$. acuminata var. montana has a strong response to the increased light availability generated by storms, particularly in juvenile trees (A. M. Sabat, unpublished manuscript). We used data on palm growth, coupled with a relative assessment of light availability (high- 
damaged sites vs. low-undamaged sites), to estimate two sets of parameters for Eq. 8, one for high light conditions (open canopy) and one for low light (closed canopy; Fig. 3), which were applied in the same manner as the seedling growth and survival parameters. For mortality, we used the same behavior we applied to the other 10 tree species (Appendix A). Since the mortality behavior requires diameter for prediction, we used allometry to estimate diameter as a function of height (data not shown).

\section{Model evaluation and simulations}

We used the parameterized model to simulate disturbance scenarios and to evaluate model efficacy. For both simulation and evaluation, we compared species composition and community- and species-level size structure between simulation "treatments" or, in the case of evaluation, between simulations and observed data from the 2000 and 2005 censuses. Initial conditions for all model runs assumed that starting densities and size distributions paralleled those of the 1990 census.

Evaluation.-To evaluate the model, we initialized it with the 1990 census map (representing conditions immediately after Hugo), simulated a hurricane at year 8 with the average severity of Hurricane Georges (in 1998), ran the model for an additional seven years, and compared the results to data from the 2000 and 2005 censuses with the matching years in the simulations (years 10 and 15, respectively). Since our simulations did not include all species in the plot, we had to reassign trees from non-represented to represented species groups to maintain overall stem densities similar to observed ones. To this end, we used data for species in our run and split them out by size class. We then multiplied each size class value by the total density and divided by the represented species density to scale all values up to reach 825 stems/ha (stem density in the 1990 census).

Typical assessments of goodness of fit for simulation models usually compare observed data to output from multiple model runs that typically vary starting conditions (e.g., Waller et al. 2004). This is not an appropriate procedure to evaluate model performance in our analysis because we only have one set of starting conditions, the 1990 census, and therefore one realization of model output for evaluation. To evaluate model fit, we calculated a chi-square test. Since we have small counts in some of the $\mathrm{dbh}$ and species count categories, we used Monte Carlo resampling with 2000 simulations (Hamilton 1991, Waller et al. 2003).

Fifteen years may seem a relatively short period in the time frame of forest dynamics to evaluate a model, but the LFDP experienced extremely high stem turnover from 1990 through 2005. During this 15-yr period community dynamics were driven by two hurricanes that caused substantial tree damage and mortality and large pulses of recruits, followed by high mortality of the thinning recruits (Zimmerman et al. 1994, Uriarte et al. 2004a). For example, following Hurricane Georges in

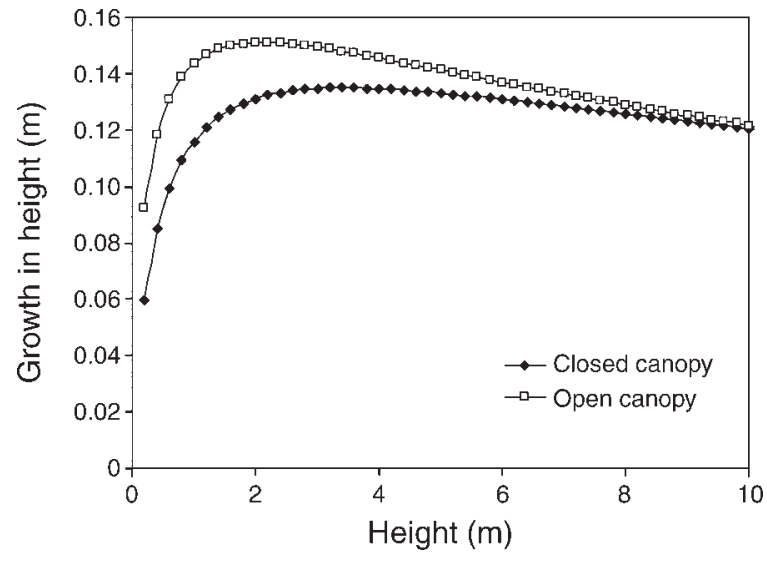

FIG. 3. Growth in height of Prestoea acuminata var. montana juveniles as a function of initial height under open and closed canopy conditions $\left(R^{2}=0.19\right)$.

1998, we recorded approximately 39000 new stems that had recruited by the 2000 census (as much as $30 \%$ recruitment per year if all recruitment happened following the hurricane; J. Thompson and J. K. Zimmerman, unpublished data). By 2005, 33000 stems had died (mostly new recruits $=6.7 \%$ mortality per yr) and only 4200 stems had recruited into the smallest size class $(0.8 \%$ recruitment per year). Thus, the $15-y r$ time frame represented in the model evaluation reflects a period of quite rapid dynamics.

Simulations.-Here we list the questions posed in the Introduction, outline the structure of simulations, and describe initial conditions for the runs.

(1) What are the implications of variation in hurricane frequency and severity for the long-term dynamics of forest composition, diversity, and structure? To address this question, we ran the model with and without hurricanes, using the two storm regimes described previously (see Model structure and parameterization: Hurricane disturbance regimes), and compared forest structure, species composition, and diversity under these three different regimes. We used plot densities observed in the 1990 census ( 825 stems/ha) as initial conditions for these runs. Initial tree species densities were estimated as described in Evaluation section.

(2) Have land use legacies from human disturbance in this forest produced alternate community structures and compositions, each with their own unique dynamics, or will communities with different land use histories converge? We used the map of initial stem densities at the time Hugo struck the LFDP and compared results in areas subject to different land use histories in the absence of hurricanes and with the historical storm regime (cyclical and non-cyclical storms). The procedure used to reassign trees of non-represented species was modified as follows. The densities of represented trees in the neighborhood of each non-represented tree were gathered. The neighborhood was defined as a square of $50 \times 50 \mathrm{~m}$ centered on the location of the non- 


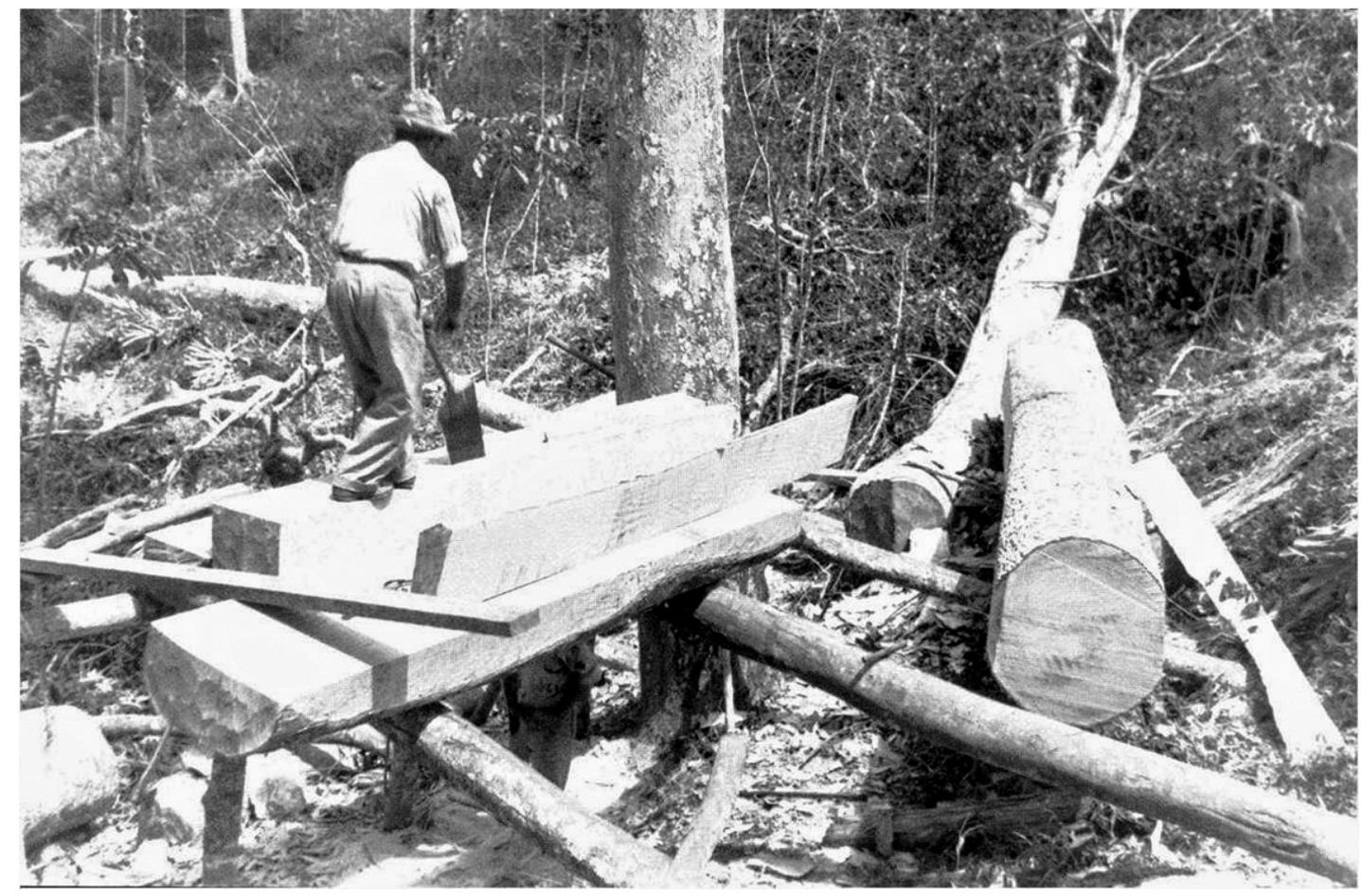

Plate 1. Logging in the Luquillo Forest Dynamics Plot, Puerto Rico, in the 1930s. Photo credit: U.S. Forest Service, International Institute of Tropical Forestry (IITF).

represented tree. The relative density of each species in this set of represented neighbors was calculated. A random number was used to select a species according to these densities. The species of non-represented trees was replaced with that of the chosen species; all other aspects (location, diameter) remained the same.

We ran each simulation for 200 years and replicated each "treatment" 10 times. For question (2), we used the Jaccard index of dissimilarity applied to average stem densities per hectare (both sapling and adult) at each time step to determine the effects of storm regimes on community convergence between areas with differing land use legacies after 200 years. The index is calculated as $2 B /(1+B)$, where $B$ is the Bray-Curtis dissimilarity index (Faith et al. 1987). The Bray-Curtis index for land use areas $j$ and $k$ is computed as

$$
d[j k]=\frac{\sum_{i=1}^{S} \operatorname{abs}(x[i j]-x[i k])}{\sum_{i=1}^{S}(x[i j]+x[i k])}
$$

where $x[i j]$ and $x[i k]$ are stem densities of species $i=$ $1,2, \ldots s$ in land use areas $j$ and $k$.

\section{RESULTS}

\section{Model evaluation}

Our simulator predicted short-term (1990-2005) changes in dbh distributions and community composi- tion in the Luquillo Forest Dynamics Plot (LFDP) quite well (Figs. 4 and 5). The model displayed a slight tendency to overestimate densities in the smaller size classes (<30 cm dbh; Fig. 4), particularly for the 2005 census $\left(2000, \chi^{2}=2.45, P=0.99 ; 2005, \chi^{2}=16.64, P=\right.$ $0.60)$, but the agreement between model and field data in the larger size classes was very high. There were differences between model and field data in the abundance of certain species, but the rank order abundance of species was well preserved (Fig. 5). Moreover, chi-square tests failed to uncover differences between predicted and observed species abundances (2000, $\chi^{2}=9.97, P=0.49 ; 2005, \chi^{2}=9.28, P=0.55$; Monte Carlo simulations, $n=2000$ ). Thus, the model appears to adequately capture this 15 -yr, very tumultuous period of forest dynamics.

\section{Model simulations}

Implications of variation in hurricane frequency and severity for the long-term dynamics of forest composition and structure.-Our first set of simulations showed that variation in storm frequency and intensity had a marked impact on stand structure. The absence of severe storms resulted in a forest with a greater number of large stems $(60-80 \mathrm{~cm} \mathrm{dbh})$ than in forests subject to these extreme events (Fig. 6). We also observed an increase in the number of saplings $(0-10 \mathrm{~cm} \mathrm{dbh})$ and small stems (10$20 \mathrm{~cm} \mathrm{dbh)} \mathrm{with} \mathrm{greater} \mathrm{storm} \mathrm{severity,} \mathrm{regardless} \mathrm{of}$ periodicity. However, multidecadal variation in the frequency of severe storms affected the degree of sapling 

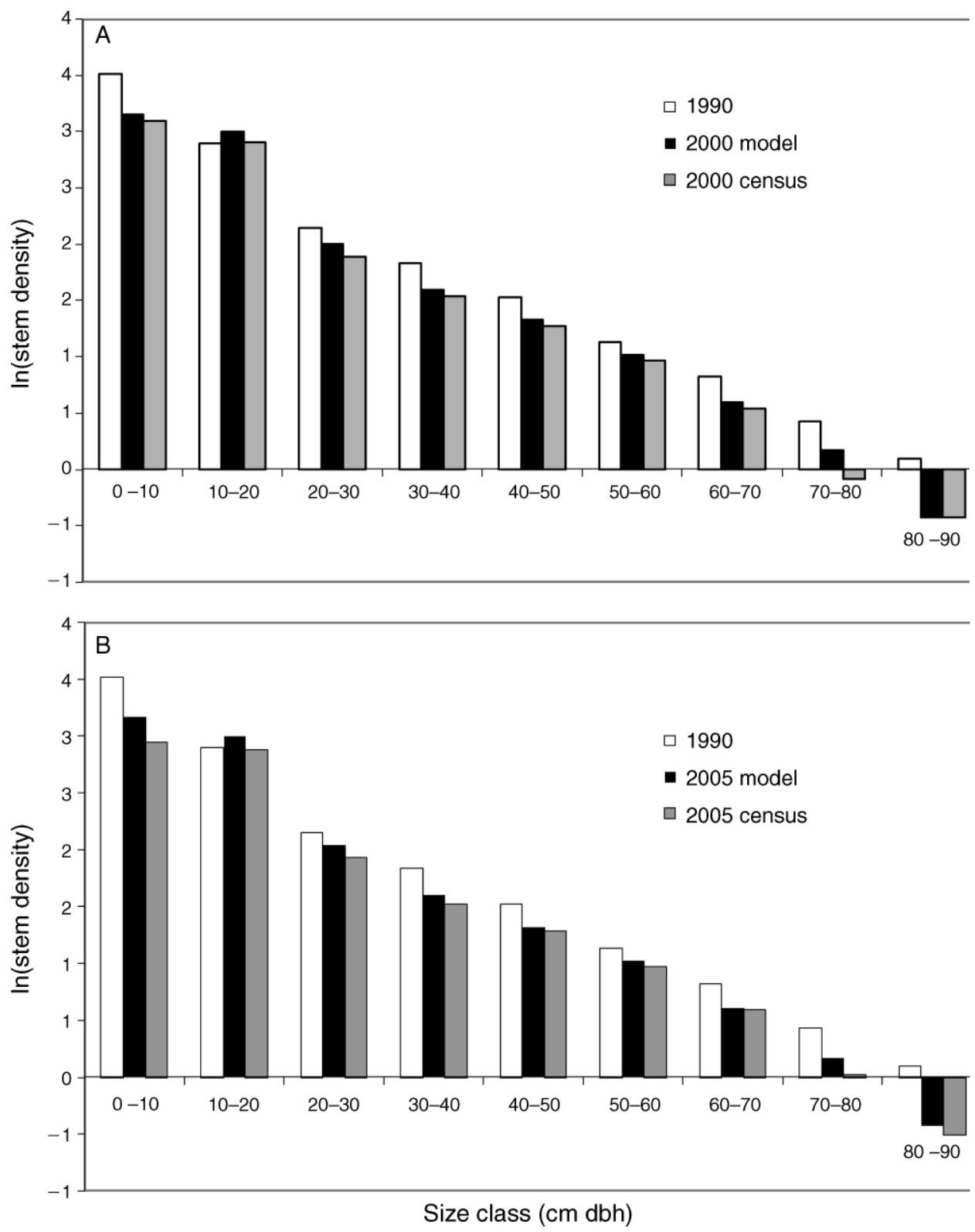

FIG. 4. Comparison of whole plot dbh distributions predicted by the simulator and those observed (A) in the 2000 and (B) in the 2005 LFDP censuses. We show starting conditions (1990 census) to illustrate the change in size distributions over the 15 years. Note that for the 1990 census data we adjusted densities as described in Methods: Model evaluation.

and small stem (10-20 $\mathrm{cm} \mathrm{dbh})$ recruitment. Under noncyclical storm regimes, continuous canopy damage led to higher sapling recruitment and densities relative to the cyclical regime. However, this difference between the two severe storm regimes was not apparent beyond the $20 \mathrm{~cm}$ dbh size cutoff. Presumably, this pattern results from an interaction between high recruitment during periods of frequent storm activity and stem thinning (i.e., high sapling mortality) during years of low storm activity. Beyond their impacts on sapling recruitment, the nature of storm regimes also affected the size distribution of adult trees. On average, cyclical storm regimes that included severe storms resulted in the highest number of stems in intermediate size classes (30$50 \mathrm{~cm} \mathrm{dbh}$ ), possibly because there was enough time between periods of frequent hurricane activity to allow stems recruited after severe storms to reach this size class. The difference between the two severe storm regimes observed in these intermediate size classes disappears at greater diameters $(>60 \mathrm{~cm})$. Periodicity of damage is likely to be less relevant to long-lived large trees.

The nature of storm regimes also had a strong effect on community composition (Figs. 7 and 8). We observed 


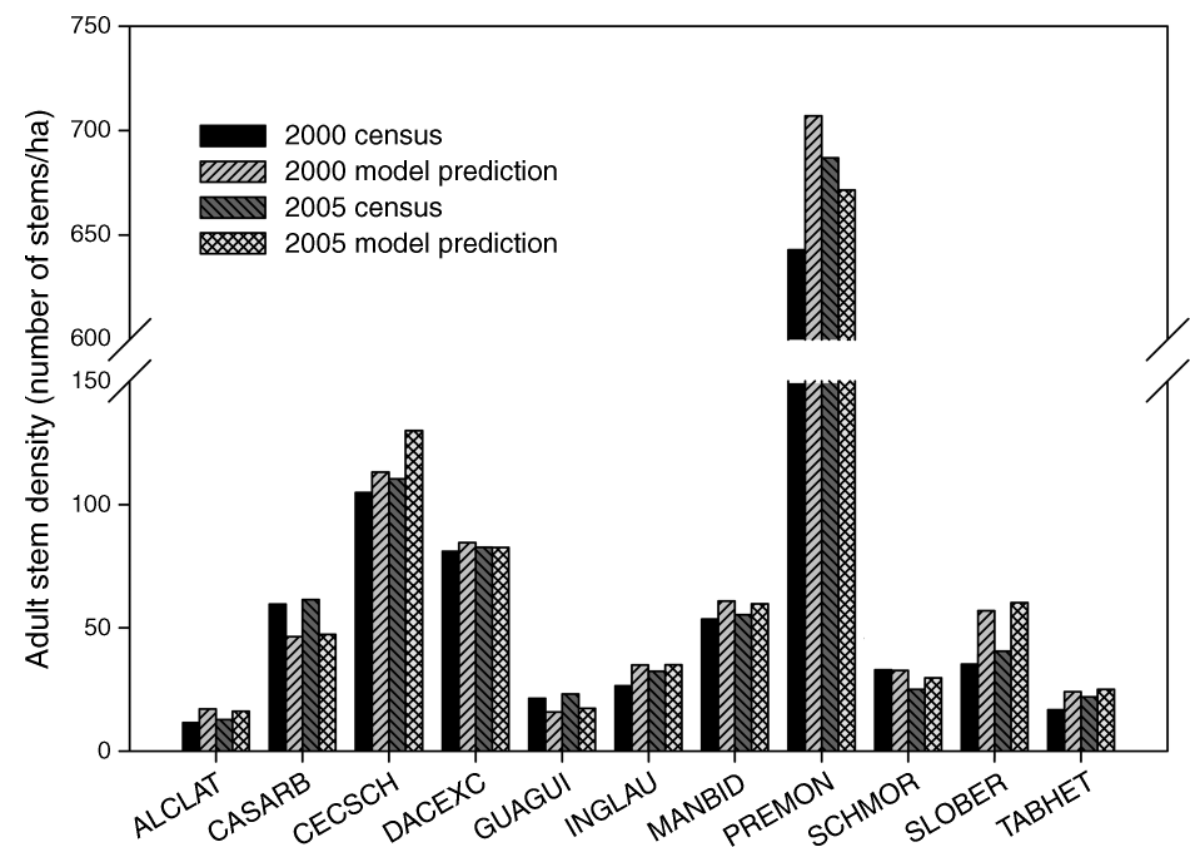

FIG. 5. Comparisons of community composition (density of adult stems [no./ha]) predicted by the simulator and census data (2000 and 2005). Note that for census data we adjusted densities as described in Methods: Model evaluation. Tree species: Alchornea latifolia (ALCLAT), Cecropia schreberiana (CECSCH), Casearia arborea (CASARB), Dacryodes excelsa (DACEXC), Guarea guidonia (GUAGUI), Inga laurina (INGLAU), Manilkara bidentata (MANBID), P. acuminata var. montana (PREMON), Schefflera morototoni (SCHMOR), Sloanea berteriana (SLOBER), and Tabebuia heterophylla (TABHET).

individualistic responses to the three different storm regimes, with some species predicted to have a greater number of stems under a regime of no severe storms $(S$. berteriana), others under severe storms with a noncyclical return pattern ( $S$. morotoni), and yet others benefited from multidecadal variation in the frequency of severe storms (D. excelsa). Our simulations also demonstrate that in the absence of storms, some species, specifically I. laurina and T. heterophylla, reach very low densities and may become locally rare.

Temporal variability in species abundances for each storm regime simulation was large (Table 3, Fig. 8). In

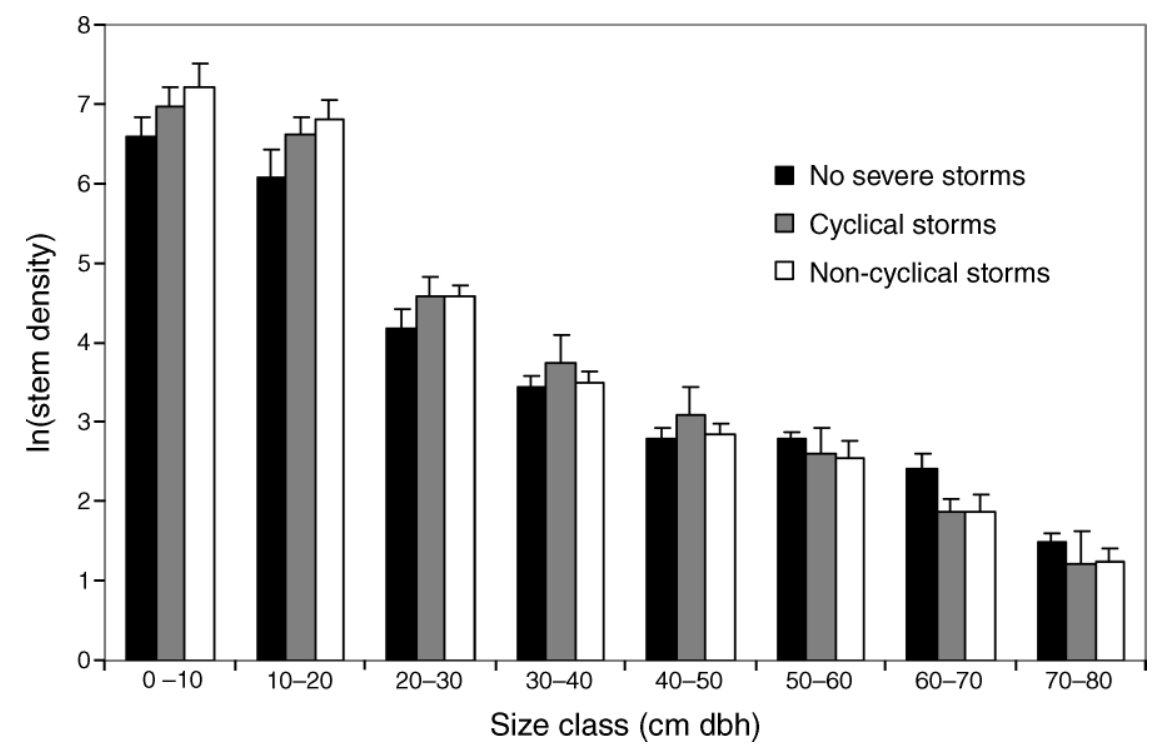

FIG. 6. Size distributions ( + SE) predicted by the simulator after 200 years, under three different storm regimes: no severe storms, cyclical storms, and non-cyclical storms. Results are mean values for 10 runs. Initial conditions represented the size distributions and relative abundance in the 1990 census but did not reproduce the spatial distribution of stems in the forest in 1990. 


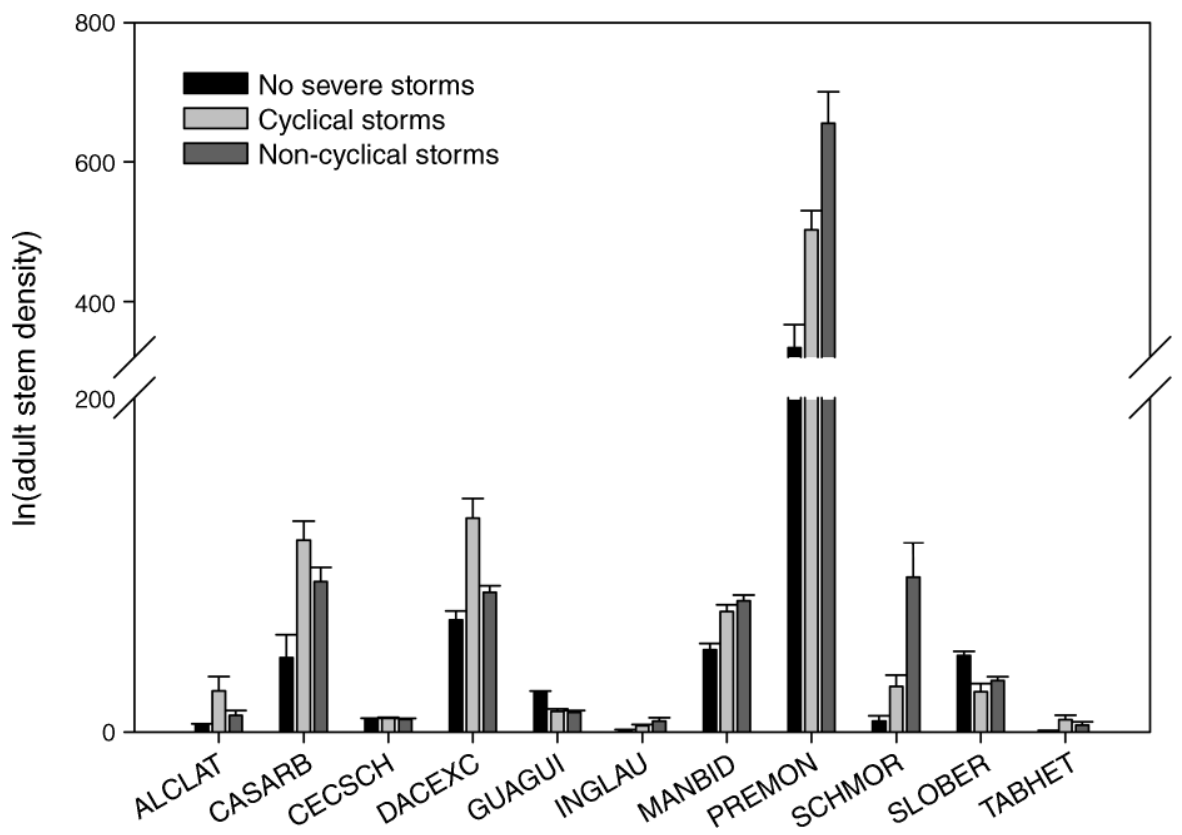

FIG. 7. Stem numbers of target species after 200 years as predicted by the simulator under three different storm regimes: no severe storms, cyclical storms, and non-cyclical storms. Letter codes for species are provided in the legend for Fig. 5. Results are mean values $(+\mathrm{SE})$ for 10 runs after 200 years. Initial conditions represented the size distributions and relative abundance in the 1990 census, but we did not retain the spatial structure of the census.
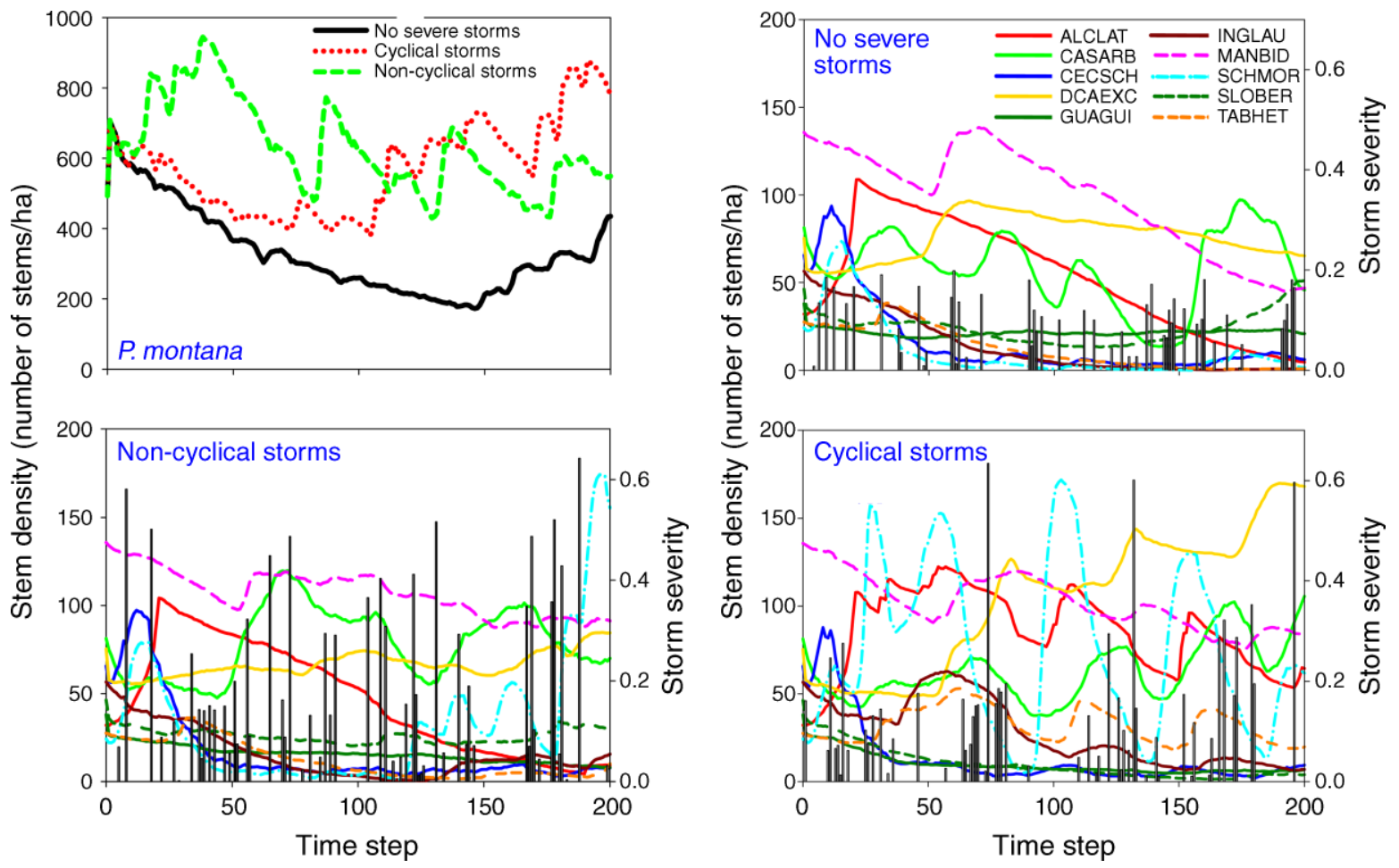

FIG. 8. Examples of community dynamics (adult stem density/ha) over 200 years under three different storm regimes. Dynamics for $P$. acuminata var. montana are shown in a separate panel to facilitate visualization of the remaining 10 species. The right-hand $y$-axis shows storm severity in a $0-1$ range and pertains to the vertical solid bars. See Fig. 5 legend for tree species. 
TABLE 3. Coefficients of variation in abundance of individual species for the last 50 years of 200 -year runs under three different storm regimes.

\begin{tabular}{lccc}
\hline \hline \multicolumn{1}{c}{ Species } & $\begin{array}{c}\text { No severe } \\
\text { storms }\end{array}$ & $\begin{array}{c}\text { Cyclical } \\
\text { storms }\end{array}$ & $\begin{array}{c}\text { Non-cyclical } \\
\text { storms }\end{array}$ \\
\hline Alchornea latifolia & 0.64 & 0.49 & 0.61 \\
Casearia arborea & 0.45 & 0.39 & 0.24 \\
Cecropia schreberiana & 0.25 & 0.33 & 0.25 \\
Dacryodes excelsa & 0.06 & 0.14 & 0.10 \\
Guarea guidonia & 0.07 & 0.16 & 0.12 \\
Inga laurina & 0.87 & 0.74 & 0.63 \\
Manilkara bidentata & 0.24 & 0.13 & 0.13 \\
Prestoea acuminata & 0.14 & 0.18 & 0.18 \\
Sloanea berteriana & 0.97 & 0.91 & 1.23 \\
Schefflera morototoni & 0.37 & 0.41 & 0.32 \\
Tabebuia heterophylla & 0.67 & 0.57 & 0.63 \\
\hline
\end{tabular}

Note: See The model: Hurricane disturbance regimes for an explanation of cyclical and non-cyclical storm regimes.

general, temporal variation was lower for late successional, shade-tolerant species (D. excelsa, G. guidonia, $M$. bidentata, and $S$. berteriana; Table 1), which generally have lower susceptibility to storm damage and slower responses to increased resource availability after storms, relative to fast growing, secondary forest species. There was a dramatic decline in the numbers of $M$. bidentata when no severe storms occurred, compared to the severe storm regimes, which was unexpected given its late successional shade tolerant status. The abundance of the pioneer C. schreberiana, initially high because of the legacies of land use and Hugo damage, showed a sharp increase in the first few years, declined in the following 10 years, and was then remarkably stable over time. A. latifolia, which is considered a high light demanding non-pioneer species, also showed a rapid increase in stem numbers in response to initial storms, but then gradually decreased in numbers over the next 200 years. On the other hand, the most temporally variable tree species was $S$. morototoni, which is also considered as a pioneer species that tends to colonize small- to medium-sized gaps. Abundance of S. morototoni showed the most dramatic temporal oscillations in frequency and amplitude under the regime of cyclical storms, but $C$. arborea showed the most variation in abundance under all three regimes and responded to storms when they were not severe, as well as cyclical and non cyclical storm frequencies that included severe storms. P. acuminata var. montana showed a gradual decline in stem numbers when there were no severe storms, and an unexpected increase in the last 50 years of the simulation that may have resulted from the overall decline in numbers of all the other species during this same time period. Cyclical storms produced the greatest variations in abundance of $P$. acuminata (compared to the other two storm regimes) during the simulation period while the non-cyclical storms caused the overall palm stem numbers to progressively increase.

Effects of land use legacies and human disturbance on community structure and compositions.-To examine the legacies of land use on forest structure and composition, we conducted a second set of simulations with initial conditions that represented the spatial structure of the forest in the 1990 census after adjusting relative abundances as described above (see The model: Simulations). Since we assumed that storm intensity was uniform across the plot, the outcome of these simulations reflects the joint effects of variation among tree species in their susceptibility to wind disturbance and in the nature of their recovery from damage. For simplicity, we will refer to areas with little land use legacies as having no land use legacies and areas that experienced more intense land use as having legacies.

In 1990, the area of the LFDP with land use legacies had more small stems $(<20 \mathrm{~cm}$ dbh) but fewer larger stems $(>20 \mathrm{~cm} \mathrm{dbh})$ than the area without previous land use history, as a consequence of the relatively recent human disturbance (Fig. 9; Thompson et al. 2002). After 200 years, for almost all dbh size classes below $50 \mathrm{~cm}$ dbh (except 10-20 cm) and under all of the three storm regimes, the number of stems in each size class was generally lower than in 1990, and the difference between the areas with and without past human disturbance had diminished. For size classes above $50 \mathrm{~cm} \mathrm{dbh}$, some combinations of land use history and storm regime increased the number of stems relative to 1990. The differences among storm regimes were small although areas without human disturbance still had a greater number of stems in the largest size class $(70-80 \mathrm{dbh})$ for all three storm regimes (Fig. 9). The model suggests that it may take longer than 200 years for some of the trees in areas that had been subjected to relatively recent human disturbance to reach this size class.

Severe hurricanes accentuated the difference in numbers of stems in areas with and without land use legacies, but only for the largest dbh size class $(70-80 \mathrm{~cm}$ dbh; Fig. 9). Severe hurricanes also resulted in a relatively higher density of intermediate-sized stems in areas that had been subjected to human land use. These relatively minor differences in stand structure between land use classes belie some striking differences in the abundance of individual species under the three storm regimes (Table 4). In fact, the land use history areas were still different (according to the Jaccard dissimilarity index) after 200 years of simulations, regardless of storm regime. Communities initially became more similar under a regime of no severe storms, but after approximately 50-75 years, severe storms increase community convergence relative to the no-storm regime, although only to a point (Fig. 10). This appears to be the result of greater recruitment for all species and more even distribution of stems across the plot under a severe storm regime (Table 4).

\section{Discussion}

Our model offers a number of insights into disturbance theory. First, it goes beyond the usual metrics of distur- 


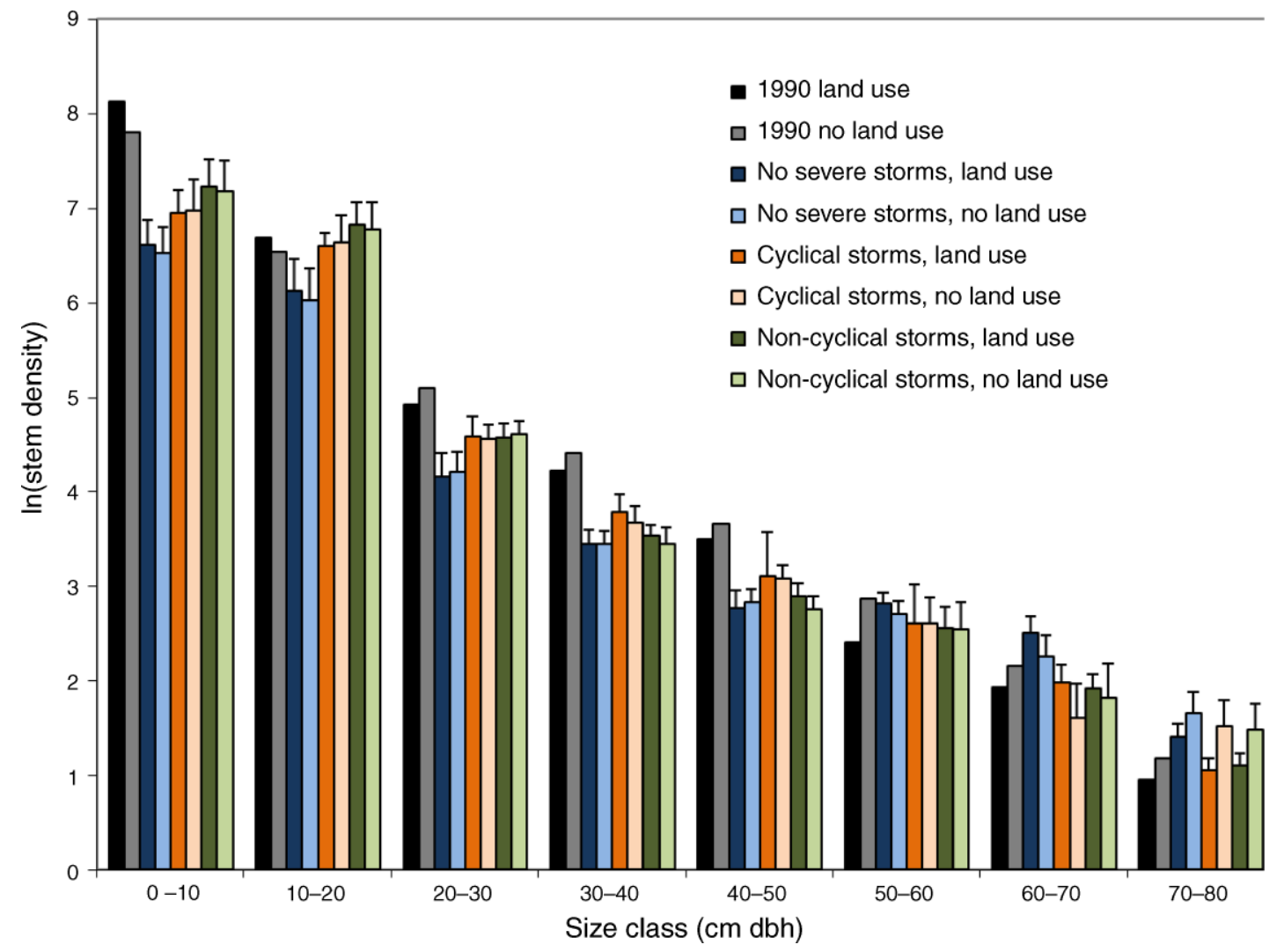

FIG. 9. Size distributions in areas with and without land use legacies at the time of the 1990 census, and the resultant size class distribution of the stem population after simulated runs for 200 years with three storm regimes. The figure depicts mean values for 10 simulations (+SE). We used the 1990 map for initial conditions, adjusting densities as we describe in Methods: Model evaluation.

bance frequency and severity, and points to understanding the temporal pattern of consecutive disturbances as a key driver of forest ecosystem dynamics. Second, by incorporating dynamic feedbacks between anthropogenic and natural disturbance, it demonstrates that this interaction may shape the degree and speed of ecosystem recovery. Third, it reveals that variation among species in life history traits that determine response to disturbance plays a key role in driving forest dynamics.

\section{Implications of variation in hurricane frequency and severity for the long-term dynamics of forest composition, diversity, and structure}

A series of devastating hurricanes in the Caribbean in the past two decades has stimulated an enormous amount of research on the effects of wind disturbance on tropical forests (e.g., Bellingham 1991, Tanner et al. 1991, Yih et al. 1991, Boucher et al. 1994). One of the most consistent lessons has been that the responses of tropical forests to hurricanes can be astonishingly swift, with "recovery" occurring on time scales of 10 years or less (Boucher et al. 1994, Scatena et al. 1996, Beard et al. 2005). These studies, which tend to focus on changes in forest structure and biomass, suggest that hurricanes represent a relatively minor perturbation to tropical forests. In contrast, a focus on community dynamics (e.g., Crow 1980, Lugo et al. 2000) indicates that hurricanes generate multidecadal changes in forest community composition, which our simulations confirm. This portrayal of a community that is constantly in flux due to repeated hurricane disturbance emphasizes the importance of the timing and magnitude of each hurricane event for its effect on the community composition at any point in time and the successional trajectory of the forest after each disturbance.

Both the severity and frequency of hurricanes had striking effects on forest dynamics, composition, and structure. Our results demonstrated that not only is the severity of hurricane disturbance key in structuring forest communities, but the temporal pattern of disturbance also plays an important role. Although there is a vast literature on cyclical disturbances and their effects on ecological communities (e.g., the effects of ENSO events on terrestrial [Wright et al. 1999] and marine [Dayton et al. 1992] communities), little is known about the implications of sustained, multidecadal patterns in the timing of disturbance events. In our simulations, periods of frequent hurricane activity create opportunities for recruitment of species that may become rare in the absence of severe storms. Quiescent periods between 
TABLE 4. Adult and sapling densities in areas with and without land use legacies in area under three storm regimes after model runs of 200 years.

\begin{tabular}{|c|c|c|c|c|c|c|c|c|c|}
\hline \multirow[b]{2}{*}{ Species } & \multirow{2}{*}{$\begin{array}{l}\text { Land use } \\
\text { history† }\end{array}$} & \multicolumn{4}{|c|}{ Adults (no./ha) } & \multicolumn{4}{|c|}{ Saplings (no./ha) } \\
\hline & & 1990 & NSS & Cycl & Non-cycl & 1990 & NSS & Cycl & Non-cycl \\
\hline Alchornea latifolia & $\begin{array}{l}\text { LU } \\
\text { NLU }\end{array}$ & $\begin{array}{l}39.6 \\
16.6\end{array}$ & $\begin{array}{l}6.4 \\
1.2\end{array}$ & $\begin{array}{l}25.8 \\
22.2\end{array}$ & $\begin{array}{r}11.2 \\
7.4\end{array}$ & $\begin{array}{r}491.8 \\
82.2\end{array}$ & $\begin{array}{l}0.9 \\
0.8\end{array}$ & $\begin{array}{l}2.4 \\
3.3\end{array}$ & $\begin{array}{l}11.1 \\
11.6\end{array}$ \\
\hline Casearia arborea & $\begin{array}{l}\text { LU } \\
\text { NLU }\end{array}$ & $\begin{array}{r}113.7 \\
14.7\end{array}$ & $\begin{array}{l}46.0 \\
41.5\end{array}$ & $\begin{array}{l}114.4 \\
115.1\end{array}$ & $\begin{array}{l}88.9 \\
92.4\end{array}$ & $\begin{array}{r}1018.9 \\
325.2\end{array}$ & $\begin{array}{l}98.5 \\
81.1\end{array}$ & $\begin{array}{l}258.9 \\
282.2\end{array}$ & $\begin{array}{l}427.6 \\
397.8\end{array}$ \\
\hline Cecropia schreberiana & $\begin{array}{l}\text { LU } \\
\text { NLU }\end{array}$ & $\begin{array}{l}63.9 \\
68.9\end{array}$ & $\begin{array}{l}8.1 \\
6.7\end{array}$ & $\begin{array}{l}8.5 \\
7.7\end{array}$ & $\begin{array}{l}8.1 \\
6.8\end{array}$ & $\begin{array}{l}801.5 \\
493.1\end{array}$ & $\begin{array}{l}42.0 \\
36.8\end{array}$ & $\begin{array}{l}31.3 \\
30.38\end{array}$ & $\begin{array}{l}40.2 \\
37.6\end{array}$ \\
\hline Dacryodes excelsa & $\begin{array}{l}\text { LU } \\
\text { NLU }\end{array}$ & $\begin{array}{r}41.1 \\
145.6\end{array}$ & $\begin{array}{l}60.9 \\
79.5\end{array}$ & $\begin{array}{l}127.7 \\
128.0\end{array}$ & $\begin{array}{l}80.4 \\
90.6\end{array}$ & $\begin{array}{r}68.4 \\
104.8\end{array}$ & $\begin{array}{l}27.6 \\
24.9\end{array}$ & $\begin{array}{l}62.59 \\
71.97\end{array}$ & $\begin{array}{l}98.8 \\
94.2\end{array}$ \\
\hline Guarea guidonia & $\begin{array}{l}\text { LU } \\
\text { NLU }\end{array}$ & $\begin{array}{l}39.9 \\
33.9\end{array}$ & $\begin{array}{l}23.5 \\
23.6\end{array}$ & $\begin{array}{l}12.4 \\
12.6\end{array}$ & $\begin{array}{l}11.2 \\
13.1\end{array}$ & $\begin{array}{r}125.1 \\
80.9\end{array}$ & $\begin{array}{l}345.2 \\
340.6\end{array}$ & $\begin{array}{l}315.08 \\
304.5\end{array}$ & $\begin{array}{l}275.2 \\
288.4\end{array}$ \\
\hline Inga laurina & $\begin{array}{l}\text { LU } \\
\text { NLU }\end{array}$ & $\begin{array}{l}52.5 \\
64.7\end{array}$ & $\begin{array}{l}1.3 \\
0.7\end{array}$ & $\begin{array}{l}3.6 \\
4.3\end{array}$ & $\begin{array}{l}6.8 \\
6.3\end{array}$ & $\begin{array}{l}134.2 \\
138.2\end{array}$ & $\begin{array}{l}2.4 \\
2.7\end{array}$ & $\begin{array}{l}5.3 \\
6.3\end{array}$ & $\begin{array}{l}36.0 \\
25.6\end{array}$ \\
\hline Manilkara bidentata & $\begin{array}{l}\text { LU } \\
\text { NLU }\end{array}$ & $\begin{array}{l}112.9 \\
182.4\end{array}$ & $\begin{array}{r}0.2 \\
47.1\end{array}$ & $\begin{array}{l}71.4 \\
73.7\end{array}$ & $\begin{array}{l}78.4 \\
78.9\end{array}$ & $\begin{array}{r}83.7 \\
135.9\end{array}$ & $\begin{array}{l}73.9 \\
62.1\end{array}$ & $\begin{array}{l}115.6 \\
116.1\end{array}$ & $\begin{array}{l}146.1 \\
136.3\end{array}$ \\
\hline Prestoea acuminata & $\begin{array}{l}\text { LU } \\
\text { NLU }\end{array}$ & $\begin{array}{l}555.6 \\
365.2\end{array}$ & $\begin{array}{l}346.2 \\
307.1\end{array}$ & $\begin{array}{l}497.9 \\
511.3\end{array}$ & $\begin{array}{l}669.8 \\
625.5\end{array}$ & $\begin{array}{l}337.2 \\
146.9\end{array}$ & $\begin{array}{l}28.2 \\
23.8\end{array}$ & $\begin{array}{l}39.4 \\
40.1\end{array}$ & $\begin{array}{l}50.8 \\
48.8\end{array}$ \\
\hline Sloanea berteriana & $\begin{array}{l}\text { LU } \\
\text { NLU }\end{array}$ & $\begin{array}{l}22.2 \\
28.2\end{array}$ & $\begin{array}{l}6.9 \\
6.03\end{array}$ & $\begin{array}{l}25.1 \\
31.8\end{array}$ & $\begin{array}{l}94.5 \\
89.2\end{array}$ & $\begin{array}{l}415.7 \\
457.2\end{array}$ & $\begin{array}{l}11.4 \\
12.9\end{array}$ & $\begin{array}{l}23.7 \\
25.9\end{array}$ & $\begin{array}{l}61.1 \\
51.5\end{array}$ \\
\hline Schefflera morototoni & $\begin{array}{l}\text { LU } \\
\text { NLU }\end{array}$ & $\begin{array}{l}27.0 \\
85.5\end{array}$ & $\begin{array}{l}47.9 \\
41.5\end{array}$ & $\begin{array}{l}23.6 \\
25.3\end{array}$ & $\begin{array}{l}30.5 \\
31.3\end{array}$ & $\begin{array}{l}122.2 \\
438.2\end{array}$ & $\begin{array}{r}114.5 \\
92.5\end{array}$ & $\begin{array}{l}183.4 \\
178.1\end{array}$ & $\begin{array}{l}203.2 \\
193.1\end{array}$ \\
\hline Tabebuia heterophylla & $\begin{array}{l}\text { LU } \\
\text { NLU }\end{array}$ & $\begin{array}{l}33.8 \\
14.3\end{array}$ & $\begin{array}{l}0.9 \\
0.5\end{array}$ & $\begin{array}{l}7.8 \\
6.9\end{array}$ & $\begin{array}{l}4.5 \\
3.8\end{array}$ & $\begin{array}{r}125.9 \\
32.4\end{array}$ & $\begin{array}{l}0.3 \\
0.6\end{array}$ & $\begin{array}{l}5.1 \\
6.3\end{array}$ & $\begin{array}{l}17.6 \\
15.1\end{array}$ \\
\hline
\end{tabular}

Notes: Key to abbreviations: NSS, no severe storms; cycl, cyclical storm regime; non-cycl, non-cyclical storm regime. Data are the means of 10 runs. Initial adjusted densities for the 1990 census are also shown for comparison.

$\dagger$ Area with previous human land use history (LU) or area with no previous land use history (NLU).

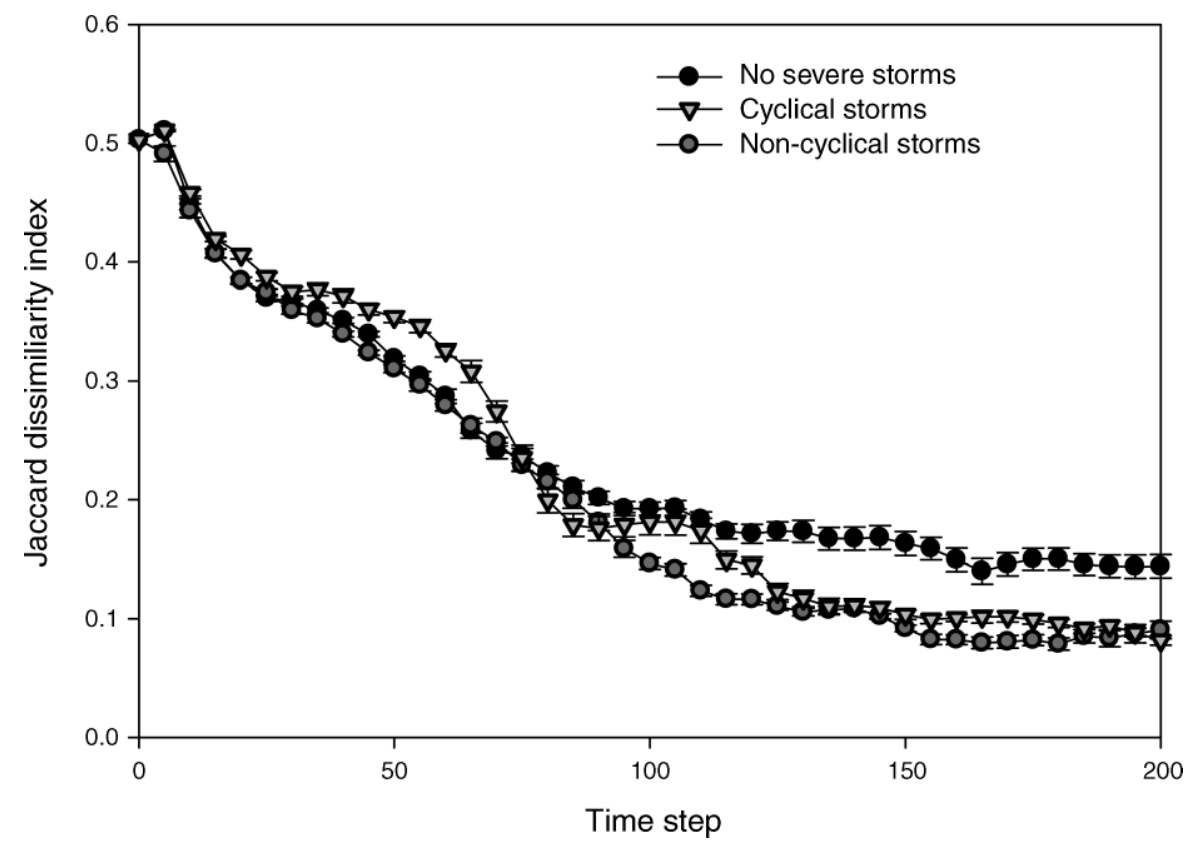

FIG. 10. Divergence in community composition between areas with and without land use legacies over 200 years under three storm regimes. Community divergence was calculated using the Jaccard dissimilarity index applied to stem density for each species at every 5-year time step. We used the 1990 map for initial conditions, adjusting densities as described in The model: Model evaluation and simulations. 
hurricanes offer a window of time in which some species may reach reproductive size classes and remain an important component of the community. The resulting community differs dramatically from that produced by a non-cyclical storm regime with the same severity and long-term frequency. If species were matched to this cyclical pattern of hurricane disturbance during evolutionary time, we would expect that multidecadal variation might prove critical to their persistence in the community (Pickett 1976).

There are major questions about whether the frequency and intensity of hurricanes are increasing as a result of anthropogenically induced global climate change (Emanuel 2005, Webster et al. 2005, Mann and Emanuel 2006, Elsner et al. 2008) or whether the recent high level of activity is related to a natural multidecadal variability in the Atlantic Ocean temperature (Goldenberg et al. 2001, Shepherd and Knutson 2007). Nevertheless, to the degree that future climate alters decadal patterns of hurricane disturbance, it should have a significant impact on the community composition of hurricane-disturbed forests (Lugo 2000).

Previous research has posited that tree species life history traits (specifically, the interaction between vulnerability to wind disturbance, ability to take advantage of enhanced light availability after storms, shade tolerance of juveniles, and a long life span) will determine the response of forest communities to wind disturbance (Loehle 2000). In our study, however, the responses of species to variation in the timing and severity of storms were not always obvious from knowledge of their life histories. For instance, the two pioneer species, which may have been expected to respond to hurricanes in similar ways, exhibited large differences in their response to storm regimes, with $S$. morotoni tracking patterns of storm cycles quite closely and C. schreberiana showing a large increase after Hugo, but becoming rare thereafter. This difference in response may reflect the unique legacies of the Luquillo Forest Dynamics Plot (LFDP) at the time of Hurricane Hugo in 1989. Similarly, primary shade-tolerant species also responded in unexpected ways. D. excelsa is a shade tolerant, late successional dominant species with low vulnerability to storm damage (Zimmerman et al. 1994, Uriarte et al. 2004a, Ogle et al. 2006, Canham et al., in press). Life history theory may have predicted that such a species would fare better than fast-growing species from the low light conditions that were common in a regime with no severe storms. Yet, a combination of rapid recovery from damage and extremely high growth under favorable light conditions generated in the wake of hurricanes lead to greater adult densities under a regime that includes severe storms (Uriarte et al. 2004a). Rapid sapling growth is not considered a typical characteristic of primary forest species. In this way this characteristic of D. excelsa resembles Simarouba amara, a primary forest species in Costa Rica (Clark and Clark 1992). In the continuum from pioneer to shade-tolerant life histories,
D. excelsa is a shade-tolerant primary forest species that germinates and persists in the shade but has the potential for rapid growth under favorable conditions such as in temporary canopy gaps or when reaching the canopy (cf. Canham 1988). These results lend support to the notion that tropical tree life histories may not obey simplistic trade-offs between shade tolerance and the light demanding characteristics, but rather display complex ontogenies in response to gradients of light availability (Swaine and Whitmore 1988, Clark and Clark 1992, Wyckoff and Clark 2002, Wen et al. 2008). The coefficient of variation in species abundances over time, which only a simulator such as ours can generate, offers another perspective on the role of life history in community dynamics. In general, species perceived to be primary forest species, such as $M$. bidentata, $G$. guidonia, and especially $D$. excelsa, behaved as expected and exhibited low temporal variation in abundance. In spite of its rapid sapling growth, D. excelsa did not exhibit substantially different temporal dynamics from those of the other primary forest species, which distinguishes it from the rest of the species in this group.

Despite some departures from expected behaviors by some species, the parameterization of SORTIE reflects overall trade-offs in the responses of species to hurricane disturbance. Uriarte et al. (2004a) demonstrated a life history trade-off between susceptibility to hurricane damage (likelihood of stem breakage or tip-up during a hurricane) and post-hurricane sapling mortality (a measure of shade tolerance), with lower susceptibility for shade-tolerant species, and these responses are incorporated into the dynamics of the model. This result follows the prevailing view that these life history trade-offs are important in the dynamics of disturbance-mediated forests (Glitzenstein and Harcombe 1988, Swaine and Whitmore 1988, Zimmerman et al. 1994, Agyeman et al. 1999, Canham et al. 2001, Moorcroft et al. 2001). Future efforts will be directed at determining their importance for the maintenance of diversity in this forest.

\section{Compound effects of human legacies and hurricanes on forest structure, composition, and dynamics}

Forests in the tropics are widely subject to human disturbance with many areas being converted to secondary forests under varying land use regimes. Experiences in Puerto Rico and other tropical regions suggest that there is a strong impact of land use history on the size, structure, species composition, and dynamics of forests (see review in Guariguata and Ostertag 2001, Chazdon 2003). Our results highlight the degree to which the age and size structure of tree populations, as influenced by past human and natural disturbance, determine the trajectory of community dynamics following subsequent disturbance. Models are, in fact, one of the few tools we have to explore the implications of the legacies of both human land use and past hurricanes for long-term tropical forest dynamics over long time scales. Legacies can be created by (1) local extirpation of 
species, which reduces the likelihood of recolonization, and (2) changes in soil resources that influence the suite of species that can establish. Our simulations included recolonization from species present in undisturbed nearby forest patches (see Uriarte et al. 2005), so dispersal of propagules of extirpated species into the adjacent area of human use should not have been strongly impeded by distance. In the absence of severe storms, our simulations indicated that legacies of land use would still be evident after 200 years, although much of the land use signature disappeared. The forest that emerged appeared to be an amalgamation of the two communities (cf. Lugo and Helmer 2004), with the species dominant in secondary forest, C. arborea, becoming more abundant in the relatively undisturbed forest. Thus, our simulations confirm the importance of understanding the effects of disturbance on the interaction between recruitment and competition in predicting the future of secondary tropical forests (Hughes et al. 2007).

Human land use leaves a legacy of a residual assemblage of species on which subsequent hurricane disturbance may act. In this forest, we might expect hurricane disturbance to either maintain or slowly eliminate land use legacies. Previously, we found that past human land use promoted greater disturbance from subsequent hurricanes (at least in the short term) because certain secondary species, such as C. arborea, that tend to be numerically dominant in areas with legacies of human land use, are also highly susceptible to hurricane disturbance. This susceptibility would open the canopy during storms, thereby promoting the establishment of pioneer species like S. morotoni and C. schreberiana (Everham 1996, Brokaw 1998, Thompson et al. 2002). This increased susceptibility acted as a positive feedback to maintain secondary forest species because pioneer species are also highly susceptible to damage (Zimmerman et al. 1994, Ogle et al. 2006, Canham et al., in press). Thus, we expected hurricane disturbance to reinforce the land use legacy evident in the LFDP. However, the simulations suggest that over time, regardless of the storm regime, the land use legacy will become less apparent. Thus, the inclusion of hurricane disturbance in the model does not alter the basic conclusion that land use legacies in this tropical forest are diminishing strongly over 200 years.

As in previous studies, our simulations also highlight the unique and contingent effects of hurricane disturbance relative to the legacies of human land use (Foster et al. 1998). Early in the last century, major hurricanes struck the LFDP area in 1928 and 1932. After a 66-yr period with relatively little hurricane damage, Hurricane Hugo struck the forest in 1989 causing significant damage (see summary in Tanner et al. 1991). This was the first major storm after the cessation of human activity in the LFDP. The composition of the community in 1989 was largely the result of the long hurricanefree period and these land use legacies, and responses to subsequent hurricanes, specifically Hurricane Georges in 1998, were quite different. Although the meteorology of the two storms was similar, the tracks of the two storms were different, and as a result Georges had much less impact on the forest. Fewer large trees fell in this second storm because individuals that had grown since the abandonment of human activity had been killed by Hurricane Hugo. The effects of these two storms on community composition were also strikingly different. For instance, there was a dramatic increase in the number of $C$. schrebriana across the LFDP after Hurricane Hugo so that many more medium-sized $C$. schreberiana were available in the forest to be damaged at the time of Hurricane Georges. In contrast, we observed little recruitment of C. schreberiana in response to damage after Hurricane Georges, potentially as a result of less canopy destruction and associated understory light after Georges. On the other hand, the pioneer $S$. morotoni, which displayed relatively low susceptibility to wind damage, showed a weaker response to Hurricane Hugo but increased dramatically after Georges, possibly because the smaller canopy gaps that were caused by Hurricane Georges were apparently more suitable for $S$. morotoni recruitment. These differences in response were the result of the timing and magnitude of hurricane disturbance and the recent land use legacies of the LFDP.

Our study supports the idea that compounded disturbances can interact in ways that cannot be predicted by the study of a single disturbance (Paine et al. 1998). Variation in recovery dynamics in ecosystems subject to these types of disturbance is usually the result of many different processes acting independently or in concert (Drury and Nisbet 1973, Foster et al. 1998, Paine et al. 1998, Platt et al. 2002). Human land use may modify existing biotic environmental relationships (Foster et al. 1998), alter natural disturbance regimes (Weir 1996; and this study), and increase the prevalence of invasive species (Horvitz et al. 1998, Thompson et al. 2007). In addition, the unique history of land use can determine the trajectory and extent of vegetation succession and recovery, making prediction and generalization difficult (Foster et al. 1998). Many tropical forests of the future will be secondary forests developing after human disturbance (IITO 2002, Chazdon 2003). The widespread importance of land use as a large-scale disturbance (Myer and Turner 1994) makes it imperative that it be addressed as a fundamental ecological process.

\section{ACKNOWLEDGMENTS}

We thank the founders of the LFDP: R. B. Waide, D. J. Lodge, C. M. Taylor, and E. M. Everham III. J. Thomlinson helped to prepare the tree maps. This work was supported by an NSF Postdoctoral Fellowship to M. Uriarte, NSF grants DEB0087214 and DEB-0516066 to C. D. Canham, J. Thompson, and M. Uriarte, and grants from NSF to the Institute for Tropical Ecosystem Studies, University of Puerto Rico, working with the International Institute of Tropical Forestry (USDA Forest Service), for the Luquillo Long-Term Ecological Research Program. The Andrew W. Mellon Foundation funded the 2000 census. The U.S. Forest Service and the University of 
Puerto Rico provided additional support. This study is a contribution to the program of the Cary Institute of Ecosystem Studies. Bruce Haines passed away in February of 2007 after a long and illustrious career. He was based at the University of Georgia and worked in the forests of Puerto Rico for over 30 years. He will be missed.

\section{Literature Cited}

Agresti, A. A. 2002. Categorical data analysis. Second edition. Wiley Press, New York, New York, USA.

Agyeman, M. D., M. Swaine, and J. Thompson. 1999. Responses of tropical forest tree seedlings to irradiance and the derivation of a light response index. Journal of Ecology 87:815-827.

Beard, K. H., K. A. Vogt, D. J. Vogt, F. N. Scatena, A. P. Covich, R. Sigurdardottir, T. G. Siccama, and T. A. Crowl. 2005. Structural and functional responses of a subtropical forest to 10 years of hurricanes and droughts. Ecological Monographs 75:345-361.

Bellingham, P. J. 1991. Landforms influence patterns of hurricane damage - evidence from Jamaican montane forests. Biotropica 23:427-433.

Boose, E. R., D. R. Foster, and M. Fluet. 1994. Hurricane impacts to tropical and temperate forest landscapes. Ecological Monographs 64:369-400.

Boose, E. R., M. I. Serrano, and D. R. Foster. 2004. Landscape and regional impacts of hurricanes in Puerto Rico. Ecological Monographs 74:335-352.

Boucher, D. H., J. H. Vandermeer, I. G. de la Cerda, M. A. Mallona, I. Perfecto, and N. Zamora. 2001. Post-agriculture versus post-hurricane succession in southeastern Nicaraguan rain forest. Plant Ecology 156:131-137.

Boucher, D. H., J. H. Vandermeer, M. A. Mallona, N. Zamora, and I. Perfecto. 1994. Resistance and resilience in a directly regenerating rain-forest-Nicaraguan trees of the Vochysiaceae after Hurricane Joan. Forest Ecology and Management 68:127-136.

Brokaw, N. V. L. 1998. Cecropia schreberiana in the Luquillo Mountains of Puerto Rico. Botanical Review 64:91-120.

Canham, C. D. 1988. An index for understory light levels in and around canopy gaps. Ecology 69:1634-1638.

Canham, C. D., M. J. Papaik, and E. F. Latty. 2001. Interspecific variation in susceptibility to windthrow as a function of tree size and storm severity for northern temperate tree species. Canadian Journal of Forest Research 31:1-10.

Canham, C. D., J. Thompson, J. K. Zimmerman, and M. Uriarte. In press. Variation in susceptibility to hurricane damage as a function of storm severity in Puerto Rican tree species. Biotropica.

Chazdon, R. L. 2003. Tropical forest recovery: legacies of human impact and natural disturbance. Perspectives in Plant Ecology, Evolution and Systematics 6:51-71.

Chesson, P. 2000. Mechanisms of maintenance of species diversity. Annual Review of Ecology and Systematics 31: 343-366.

Clark, D. A., and D. B. Clark. 1992. Life history diversity of canopy and emergent trees in a neotropical rain forest. Ecological Monographs 62:315-344.

Clark, D. B. 1996. Abolishing virginity. Journal of Tropical Ecology 12:735-739.

Clark, J. S., J. Mohan, M. Dietze, and I. Ibanez. 2003. Coexistence: how to identify trophic trade-offs. Ecology 84: $17-34$.

Clark, J. S., et al. 2001. Ecological forecasts: an emerging imperative. Science 293:657-660.

Coates, K. D., C. D. Canham, M. Beaudet, D. L. Sachs, and C. Messier. 2003. Use of a spatially-explicit individual tree model to explore the implications of patchiness in structurally complex forests. Forest Ecology and Management 186: 297-310.
Condit, R. 1998. Tropical forest census plots: methods and results from Barro Colorado Island, Panama, and a comparison with other plots. Springer-Verlag, Berlin, Germany.

Cooper-Ellis, S., D. R. Foster, G. Carlton, and A. Lezberg. 1999. Forest response to catastrophic wind: results from an experimental hurricane. Ecology 80:2683-2696.

Crow, T. R. 1980. A rainforest chronicle: a 30-year record of change in structure and composition at El Verde, Puerto Rico. Biotropica 12:42-55.

Dambrine, E., J. L. Dupouey, L. Laüt, L. Humbert, M. Thinon, T. Beaufils, and H. Richard. 2007. Present forest biodiversity patterns in France related to former Roman agriculture. Ecology 88:1430-1439.

Dayton, P. K., M. J. Tegner, P. E. Parnell, and P. B. Edwards. 1992. Temporal and spatial patterns of disturbance and recovery in a kelp forest community. Ecological Monographs 62:421-445.

Drury, W. H., and I. C. T. Nisbet. 1973. Succession. J. Arnold Arboretum 54:331-368.

Dupouey, J. L., E. Dambrine, J. D. Laffite, and C. Moares. 2002. Irreversible impact of past land use on forest soils and biodiversity. Ecology 83:2978-2984.

Elsner, J., J. P. Kossin, and T. H. Jagger. 2008. The increasing intensity of the strongest tropical cyclones. Nature 445:92-95.

Emanuel, K. A. 2005. Increasing destructiveness of tropical cyclones over the past 30 years. Nature 436:686-688.

Everham, E. M., III. 1996. Hurricane damage and recovery: an empirical and simulation study of vegetation dynamics in the Luquillo Experimental Forest, Puerto Rico. Dissertation. College of Environmental Science and Forestry, State University of New York, Syracuse, New York, USA.

Everham, E. M., and N. V. L. Brokaw. 1996. Forest damage and recovery from catastrophic wind. Botanical Review 62: $113-185$.

Ewel, J. J., and J. L. Whitmore. 1973. The ecological life zones of Puerto Rico and the U.S. Virgin Islands. Forest Service Research Papers ITF-18. International Institute of Tropical Forestry, Rio Piedras, Puerto Rico, USA.

Faith, D. P., P. R. Minchin, and L. Belbin. 1987. Compositional dissimilarity as a robust measure of ecological distance. Vegetatio 69:57-68.

Fernandez, D. S., and N. Fetcher. 1991. Changes in light availability following Hurricane Hugo in a subtropical montane forest in Puerto Rico. Biotropica 23:393-399.

Foster, D. R., M. Fluet, and E. R. Boose. 1999. Human or natural disturbance: landscape-scale dynamics of the tropical forests of Puerto Rico. Ecological Applications 9:555-572.

Foster, D. R., G. Motzkin, and B. Slater. 1998. Land use history as long-term, broad scale disturbance: regional forest dynamics in central New England. Ecosystems 1:96-119.

Foster, D. R., F. Swanson, J. Aber, I. Burke, N. Brokaw, D. Tilman, and A. Knapp. 2003. The importance of land-use legacies to ecology and conservation. BioScience 53:77-88.

Frazer, G. W., C. D. Canham, and K. P. Lertzman. 1999. Gap light analyzer. Version 2.0. Imaging software to extract canopy structure and gap light transmission indices from true-colour fisheye photographs: users' manual and program documentation. Simon Fraser University, Burnaby, British Columbia, Canada, and the Institute of Ecosystems Studies, Millbrook, New York, USA.

Frazer, G. W., R. A. Fournier, J. A. Trofymow, and R. J. Hall. 2001. A comparison of digital and film fisheye photography for analysis of forest canopy structure and gap light transmission. Agricultural and Forest Meteorology 109: 249-263.

Freelich, L. E., and P. B. Reich. 1999. Neighborhood effects, disturbance severity, and community stability in forests. Ecosystems 2:151-166.

García-Montiel, D. C. 2002. El legado de la actividad humana en los bosques neotropicales contemporáneos. Pages 97-116 
in M. Guariguata and G. Kattan, editors. Ecología y Conservación de Bosques Neotropicales. Libro Universitario Regional, Cartago, Costa Rica.

Glitzenstein, J. S., and P. A. Harcombe. 1988. Effects of the December 1983 tornado on forest vegetation of the Big Thicket, southeast Texas, USA. Forest Ecology and Management 25:29-290.

Goldenberg, S. B., C. W. Landsea, A. M. Mestas-Núñez, and W. M. Gray. 2001. The recent increase in Atlantic hurricane activity: causes and implications. Science 293:474-479.

Gómez-Pompa, A., and A. Kaus. 1992. Taming the wilderness myth. BioScience 42:271-279.

Grau, H. R., T. M. Aide, J. K. Zimmerman, J. R. Thomlinson, E. Helmer, and X. Zou. 2003. The ecological consequences of socioeconomic and land use changes in postagriculture Puerto Rico. BioScience 53:1159-1168.

Gray, W. M. 1975. Tropical cyclone genesis. Atmospheric Science Paper Number 24. Department of Atmospheric Science, Colorado State University, Fort Collins, Colorado, USA.

Grove, S. J., S. M. Turton, and D. T. Siegenthaler. 2000. Mosaics of canopy openness induced by tropical cyclones in lowland rain forests with contrasting management histories in northeastern Australia. Journal of Tropical Ecology 16: 883-894.

Guariguata, M. R., and R. Ostertag. 2001. Neotropical secondary forest succession: changes in structural and functional characteristics. Forest Ecology and Management 148:185-206.

Guzmán-Grajales, S., and L. R. Walker. 1991. Differential seedling responses to litter after Hurricane Hugo in the Luquillo Experimental Forest in Puerto Rico. Biotropica 23: 407-413.

Hamilton, M. A. 1991. Model validation: an annotated bibliography. Communication Statistics: Theory and Methods 20:2207-2266.

Holling, C. S. 2001. Understanding the complexity of economic, ecological, and social systems. Ecosystems 4:390-405.

Horvitz, C. C., J. B. Pascarella, S. McMann, A. Freedman, and R. H. Hofstetter. 1998. Functional roles of invasive nonindigenous plants in hurricane-affected subtropical hardwood forests. Ecological Applications 8:947-974.

Hughes, A. R., J. E. Byrnes, D. L. Kimbro, and J. J. Stachowicz. 2007. Reciprocal relationships and potential feedbacks between biodiversity and disturbance. Ecology Letters 10:849-864.

ITTO. 2002. ITTO guidelines for the restoration, management and rehabilitation of degraded and secondary tropical forests. International Tropical Timber Organization (ITTO) Policy development series Number 13.

Johnson, J. B., and K. S. Omland. 2004. Model selection in ecology and evolution. Trends in Ecology and Evolution 19: 101-108.

Levin, S. A., and R. T. Paine. 1974. Disturbance, patch formation, and community structure. Proceedings of the National Academy of Science (USA) 71:2744-2747.

Liogier, H. A. 1985. Descriptive flora of Puerto Rico and adjacent islands. Volumes I-V. Editorial de la Universidad de Puerto Rico, Rio Piedras, Puerto Rico, USA.

Loehle, C. 2000. Strategy space and the disturbance spectrum: a life-history model for tree species coexistence. American Naturalist 156:14-33.

Losos, E., and E. G. Leigh, Jr., editors 2004. Tropical forest diversity and dynamism: findings from a large scale plot network. University of Chicago Press, Chicago, Illinois, USA.

Lugo, A. E. 2000. Effects and outcomes of Caribbean hurricanes in a climate change scenario. Science of the Total Environment 262:243-251.

Lugo, A. E., J. Figueroa Colon, and F. N. Scatena. 2000. The Caribbean. Chapter 16 in M. G. Barbour and W. D. Billings, editors. North American terrestrial vegetation. Cambridge University Press, Cambridge, UK.

Lugo, A. E., and E. Helmer. 2004. Emerging forests on abandoned land: Puerto Rico's new forests. Forest Ecology and Management 190:145-161.

Mabry, C. M., S. P. Hamburg, T. C. Lin, F. W. Horng, H. B. King, and Y. J. Hsia. 1998. Typhoon disturbance and standlevel damage patterns at a subtropical forest in Taiwan. Biotropica 30:238-250.

Mann, M. E., and K. A. Emanuel. 2006. Atlantic hurricane trends linked to climate change. EOS: transactions of the American Geophysical Union 87:233-244.

Margalef, R. 1968. Perspectives in ecological theory. University of Chicago Press, Chicago, Illinois, USA.

McNab, W. H., C. H. Greenberg, and E. C. Berg. 2004. Landscape distribution and characteristics of large hurricanerelated canopy gaps in a southern Appalachian watershed. Forest Ecology and Management 196:435-447.

Miner Solá, E. 2000. Historia de los Hurracanes en Puerto Rico. First Book Publishing of Puerto Rico, San Juan, Puerto Rico, USA.

Moorcroft, P. R., G. C. Hurtt, and S. W. Pacala. 2001. A method for scaling vegetation dynamics: the ecosystem demography model (ED). Ecological Monographs 71:557-585.

Myer, W. B., and B. L. Turner II, editors 1994. Changes in land use and land cover: a global perspective. Cambridge University Press, Cambridge, UK.

Ogle, K., M. Uriarte, J. Thompson, J. Johnstone, A. Jones, Y. Lin, E. McIntire, and J. Zimmerman. 2006. Implications of vulnerability to hurricane damage for long-term survival of tropical tree species: a Bayesian hierarchical analysis. In J. S. Clark and A. E. Gelfand, editors. Applications of computational statistics in the environmental sciences: hierarchical Bayes and MCMC methods. Oxford University Press, Oxford, UK.

Ostertag, R., W. L. Silver, and A. E. Lugo. 2005. Factors affecting mortality and resistance to damage following hurricanes in a rehabilitated subtropical moist forest. Biotropica 37:16-24.

Pacala, S. W., C. D. Canham, J. Saponara, J. A. Silander, Jr., R. K. Kobe, and E. Ribbens. 1996. Forest models defined by field measurements: estimation, error analysis, and dynamics. Ecological Monographs 66:1-43.

Pacala, S. W., C. D. Canham, J. A. Silander, Jr., and R. K. Kobe. 1994. Sapling growth as a function of resources in a north temperate forest. Canadian Journal of Forest Research 24:2172-2183.

Paine, R. T., M. J. Tagener, and E. A. Johnson. 1998. Compounded perturbations yield ecological surprises. Ecosystems 1:535-545.

Pascarella, J. B., T. M Aide, and J. K. Zimmerman. 2004. Short-term response of secondary forests to hurricane disturbance in Puerto Rico, USA. Forest Ecology and Management 199:379-393.

Peterson, C. J., and S. T. A. Pickett. 1991. Stem damage and resprouting following catastrophic windthrow in an old-growth hemlock-hardwoods forest. Forest Ecology and Management 42:205-217.

Pickett, S. T. A. 1976. Succession: an evolutionary interpretation. American Naturalist 110:107-119.

Pickett, S. T. A., M. L. Cadenasso, and J. M. Grove. 2005. Biocomplexity in coupled natural-human systems: a multidimensional framework. Ecosystems 8:225-232.

Pickett, S. T. A., V. T. Parker, and P. L. Fielder. 1992. The new paradigm in ecology: implications for conservation biology above the species level. Pages 65-88 in P. L. Fiedler and S. K. Jain, editors. Conservation biology: the theory and practice of nature conservation, preservation, and management. Chapman and Hall, New York, New York, USA.

Pickett, S. T. A., and P. S. White, editors. 1985. Natural disturbance and patch dynamics: an introduction. The 
ecology of natural disturbance and patch dynamics. Academic Press, Orlando, Florida, USA.

Platt, W. J., B. Beckage, R. F. Doren, and H. H. Slater. 2002. Interactions of large-scale disturbances: prior fire regimes and hurricane mortality of savanna pines. Ecology 83:1566-1572.

Platt, W. J., R. F. Doren, and T. V. Armentano. 2000. Effects of Hurricane Andrew on stands of slash pine (Pinus elliottii var. densa) in the everglades region of south Florida (USA). Plant Ecology 146:43-60.

Ribbens, E., J. A. Silander, and S. W. Pacala. 1994. Seedling recruitment in forests: calibrating models to predict patterns of tree seedling dispersion. Ecology 75:1794-1806.

Romme, W. H., E. H. Everham, L. E. Frelich, M. A. Moritz, and R. E. Sparks. 1998. Are large, infrequent disturbances qualitatively different from small frequent disturbances? Ecosystems 1:524-534.

Scatena, F. N., S. Moya, C. Estrada, and J. D. Chinea. 1996. The first five years in the reorganization of aboveground biomass and nutrient use following Hurricane Hugo in the Bisley Experimental Watersheds, Luquillo Experimental Forest, Puerto Rico. Biotropica 28:424-440.

Shea, K., S. H. Roxburgh, and E. S. J. Rauschert. 2004. Moving from pattern to process: coexistence mechanisms under intermediate disturbance regimes. Ecology Letters 7:491-508.

Shepherd, J. M., and T. Knutson. 2007. The current debate on the linkage between global warming and hurricanes. Geography Compass 1:1-24.

Soil Survey Staff. 1995. Order 1 Soil Survey of the Luquillo Long-Term Ecological Research Grid, Puerto Rico. USDA, Natural Resources Conservation Service, Lincoln, Nebraska, USA.

Swaine, M. D., and T. C. Whitmore. 1988. On the definition of ecological species groups in tropical rain forests. Vegetatio 75:81-86.

Tanner, E. V. J., V. Kapos, and J. R. Healey. 1991. Hurricane effects on forest ecosystems in the Caribbean. Biotropica 23: $513-521$.

Thompson, J., N. Brokaw, J. K. Zimmerman, R. B. Waide, E. M. Everham III, D. J. Lodge, C. M. Taylor, D. GarcíaMontiel, and M. Fluet. 2002. Land use history, environment, and tree composition in a tropical forest. Ecological Applications 12:1344-1363.

Thompson, J., A. E. Lugo, and J. Thomlinson. 2007. Land use history, hurricane disturbance, and the fate of introduced species in a subtropical wet forest in Puerto Rico. Plant Ecology 192:289-301.

Uriarte, M., C. D. Canham, J. Thompson, and J. K. Zimmerman. 2004a. A maximum-likelihood, neighborhood analysis of tree growth and survival in a tropical forest. Ecological Monographs 71:591-614.

Uriarte, M., C. D. Canham, J. Thompson, J. K. Zimmerman, and N. Brokaw. 2005. Seedling recruitment in a hurricanedriven tropical forest: light limitation, density dependence and the spatial distribution of parent trees. Journal of Ecology 93:291-304.

Uriarte, M., and M. Papaik. 2007. Hurricane impacts on dynamics, structure, and carbon sequestration of forest ecosystems in Southern New England. Tellus 59A:519-528.
Uriarte, M., L. W. Rivera, J. K. Zimmerman, T. M. Aide, A. G. Power, and A. Flecker. 2004b. Interactions between land use history and hurricane damage in a neotropical forest. Plant Ecology 174:49-58.

Vandermeer, J., D. Boucher, I. Perfecto, and I. Granzo de la Cerda. 1996. A theory of disturbance and species diversity: evidence from Nicaragua after Hurricane Joan. Biotropica 28:600-613.

Walker, L. R. 1991. Tree damage and recovery from Hurricane Hugo in Luquillo Experimental Forest, Puerto Rico. Biotropica 23:379-385.

Walker, L. R., D. J. Lodge, S. M. Guzmán-Grajales, and N. Fetcher. 2003. Species-specific seedling responses to hurricane disturbance in a Puerto Rican rain forest. Biotropica 35: $472-485$.

Waller, L. A., D. Smith, J. E. Childs, and L. A. Real. 2003. Monte Carlo assessments of goodness of fit for ecological simulation models. Ecological Modellling 164:49-63.

Walsh, R. P. D. 1996. Climate. Pages 159-205 in P. W. Richards, editor. The tropical rainforest: an ecological study. Second edition. Cambridge University Press, Cambridge, UK.

Webster, P. J., G. J. Holland, J. A. Curry, and H. R. Chang. 2005. Changes in tropical cyclone number, duration, and intensity in a warming environment. Science 309:1844-1846.

Weir, J. M. H. 1996. The fire frequency and age mosaic of a mixed wood boreal forest. Thesis. University of Calgary, Calgary, Canada.

Wen, S., N. Fetcher, and J. K. Zimmerman. 2008. Acclimation responses of tropical tree species to hurricane disturbance: ontogenetic differences. Tree Physiology 28:935-946.

Wright, S. J., C. Carrasco, O. Calderón, and S. Paton. 1999. The El Niño Southern Oscillation variable fruit production, and famine in a tropical forest. Ecology 80:1632-1647.

Wu, J., and O. L. Loucks. 1995. From balance of nature to hierarchical patch dynamics. Quarterly Review of Biology 70: 439-466.

Wyckoff, P. H., and J. S. Clark. 2002. The relationship between growth and mortality for seven co-occurring tree species in the southern Appalachian Mountains. Journal of Ecology 90: 604-615.

Yih, K., D. H. Boucher, J. H. Vandermeer, and N. Zamora. 1991. Recovery of rain forest of southeastern Nicaragua after destruction by Hurricane Joan. Biotropica 23:106-113.

You, C., and W. H. Petty. 1991. Effects of Hurricane Hugo on Manilkara bidentata, a primary tree species in the Luquillo Experimental Forest in Puerto Rico. Biotropica 23: 106-113.

Zimmerman, J. K., T. M. Aide, M. Rosario, M. Serrano, and L. Herrera. 1995. Effects of land management and a recent hurricane on forest structure and composition in the Luquillo Experimental Forest, Puerto Rico. Forest Ecology and Management 77:65-76.

Zimmerman, J. K., E. M. Everham, R. B. Waide, D. J. Lodge, C. M. Taylor, and N. V. L. Brokaw. 1994. Responses of tree species to hurricane winds in subtropical wet forest in Puerto Rico-implications for tropical tree life histories. Journal of Ecology 82:911-922.

\section{APPENDIX A}

List of behaviors, URLs for detailed description of behaviors, and references (Ecological Archives M079-015-A1).

\section{APPENDIX B}

Results of regression analyses of seedling root diameter growth as a function of diameter (Ecological Archives M079-015-A2). 